\title{
A KESZTHELY-KULTÚRA MA
}

\author{
MÜLLER RÓBERT*
}

\begin{abstract}
A Keszthely-kultúra fogalma az elmúlt 130 év alatt sokat változott. Az 568 és 630-650 közé keltezhető korai szakasz létét többen kétségbe vonták. A korai szakasz 11 lelőhelyét áttekintve a dolgozat azt igyekszik igazolni, hogy a korai avar korban relatív önállósággal bíró, Keszthely környéki keresztény népességet a tovább élő késő antik elemeken kívül döntően a kelet alpi, dalmáciai, balkáni és germán területekröl bevándoroltak alkották. Megjelölésükre a Keszthely-kultúra korai szakasza a megfelelő elnevezés. A késői szakasz a korai szerves folytatása.
\end{abstract}

Kulcsszavak: Keszthely-kultúra, Keszthely-Fenékpuszta, korai avar kor, kontinuitás, bevándorlás, betelepités

The concept of the Keszthely culture has changed significantly over the past 130 years. The legitimacy of the early phase dated between 568 and 630-650 has been challenged by some scholars. By reviewing eleven sites of the culture's early phase, this study seeks to demonstrate that in addition to surviving late antique elements, the Christian population that lived in the Keszthely area and enjoyed a relative measure of independence was predominantly made up eastern Alpine, Dalmatian, Balkanic and Germanic immigrants. The label "early phase of the Keszthely culture" seems an adequate term for their description. The culture's late phase is an organic continuation of the early one.

Keywords: Keszthely culture, Keszthely-Fenékpuszta, Early Avar period, continuity, immigration, settlement

Lipp Vilmos 1879 és 1886 között négy keszthelyi és Keszthely környéki temetőben 5067 sírt tárt fel. ${ }^{1}$ Az elókerült mellékletek még alig voltak ismertek a Kárpát-medencéből. Több korai munkájában jól sejtette, hogy ez a leletanyag az avar korra keltezhető, de végül is - Hampel József hatására - a sírokból előkerült kopott késő császárkori érmek alapján 4-5. századi, betelepített barbároknak határozta meg az itt eltemetetteket. ${ }^{2}$ A leletanyagot először Ludwig Lindenschmit nevezte el Keszthely-kultúrának. ${ }^{3}$ A kifejezést a

\footnotetext{
* Kézirat beérkezett: 2020. május 27. Kézirat elfogadva: 2020. július 27.

* Müller Róbert, Balatoni Múzeum; 8360 Keszthely, Múzeum utca 2.; e-mail: mullerrobi@gmail.com

1 KIss 2011, 500, Tab. 3. Egyik temetót sem tárta fel teljesen, a temetők sírszáma 11 000-re becsülhető. A későbbiekben Csák Árpád és Kovrig Ilona még több száz sírt tárt fel ezekben a temetőkben.

2 LiPP 1884, 50-51; KIss 2011, 493 Tab. 2.

3 LINDENSCHMIT 1889.
}

kutatás elfogadta, de az egyes kutatók keltezése és etnikai meghatározása eltéró volt, a 4 . századtól a Karoling-korig, a szarmatáktól a hunokon és a különböző germán népeken át az avarokig és az általuk betelepített népekig. ${ }^{4}$ A Keszthely városi, a keszthely-dobogói és a páhoki (hévízi) temetőkból ismert griffes-indás övgarnitúrákról Rhé Gyula állapította meg a Veszprém megyei leletek alapján, hogy az avarokhoz köthetők. ${ }^{5}$ Alföldi András érdeme, hogy megállapította, a keszthely-fenékpusztai temetőból ismert kosárkás függők, korongfibulák, stílustúk és kígyófejes karperecek szinte csak Keszthely környékéről ismertek, és ezek az autochton késó római lakosság hagyatékának tekinthetők, akik itt megérték az avar kort. ${ }^{6}$ A Keszthely-kultúra értékelésében alapvetó Kovrig Ilona munkássága, aki a páhoki (hévízi) és a Keszthely városi temetőben is folytatta Lipp ásatását. Véleménye szerint a Keszt-

\footnotetext{
4 MÜLler 1992, 251-252; KISS 2011, 492-495.

5 RHÉ 1924.

6 AlFÖLDI 1926, 45-60.
} 
hely-kultúra fogalmából ki kell zárni a griffes-indás késő avar népességet, és csak az a leletanyag sorolható a kultúrához, ami a kosaras függőkkel, korongfibulákkal, stílustúkkel, majd valamivel később a kígyófejes karperecekkel jellemezhető.? Ezek a tárgyak, eltekintve néhány Pécs környéki lelőhelytől, csak Keszthelyen és egy kb. 30 km átmérójú körzetéből ismertek. Abban egyetértett Alföldivel, hogy ez a leletanyag a tovább élö, késő antik népességhez köthető, és a továbbélés lehetőségét sem zárta ki, de tekintve, hogy Fenékpusztán a késő császárkori és a 6. századi leletek között hiátus van, a többi lelőhelyen pedig semmilyen előzménye nincs ennek a népességnek, felvetette, hogy talán csak a kora avar korban telepedett meg Keszthely környékén egy új népesség. A leletek alapján arra következtetett, hogy ez a népesség csak a 7. század első harmadáig lakott az erődben, és annak elpusztítását követóen a lakosságot áttelepítették Keszthelyre.

Kovrig tanulmányát követően kerültek jól dokumentált módon feltárásra, majd közlésre a fenékpusztai erőd területén és környékén különböző kora avar kori sírok, temetók: az ókeresztény bazilikában, ${ }^{8}$ a horreum mellett, ${ }^{9}$ a déli eródfal előtt, ${ }^{10}$ a Fenéki út mentén ${ }^{11}$ és a Pusztaszentegyházi dúlóben, ${ }^{12}$ illetvea Lesencetomaj-Piroskereszt lelőhelyen a 7. század közepén megnyitott, és a 9. század elejéig használt temető, amelyből eddig 1790 sírt ismerünk. ${ }^{13}$ Ezek a feltárások indokolták, hogy a Keszthely-kultúrán belül egy korai és egy késői fázist különítsünk el. ${ }^{14}$ A korai szakaszra elsősorban a női sírokból előkerült késő antik, bizánci kosarasfüggők, poliéder végü függők, különböző típusú ruhatúk, korong alakú dobozfibulák, állatfibulák, hajhálók aranycsövecskéi, bizánci gallérdísz, illetve germán cloisonné csüngők, aranygyöngyök, S-fibulák, kengyelfibulák és a férfi sírokból elókerült préselt, sok mellékszíjas, pajzsos-kettőspajzsos veretekkel díszített, a korai avar temetőkből is ismert övgarnitúrák (álcsatos, Martinovka-, Fönlak-típus) vagy az öntött, itáliai (kelet-alpi) övgarnitúrák voltak jellemzőek. Ezek a horreumnál, a bazilikában, a Fenéki úton aranyból és ezüstból készültek, a déli erődfal előtt és a Pusztaszentegyházi dűlőben ezüstből és bronzból. A temetkezési rítus és a bazilika használata egyértelmúvé teszi, hogy ezekbe a temetőkbe keresztényeket temettek el.

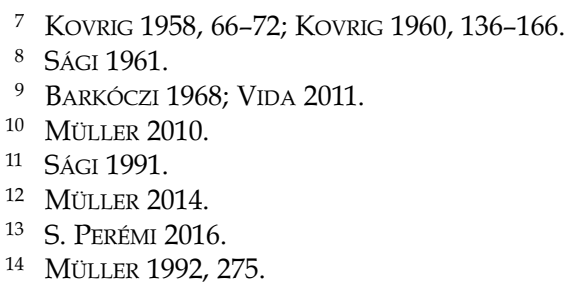

Kiss Attila, Tóth Endre és Volker Brierbauer szerint ez a keresztény népesség a helyben tovább élő késő császárkori lakosság utódaival azonosítható. ${ }^{15}$ Írott források igazolják, hogy az egykori Pannonia antik népessége az 5-6. század folyamán az elvándorlás következtében folyamatosan csökkent, de szórványos jelenlétükkel számolnunk kell a kora avar kori Dunántúlon, ${ }^{16}$ ahol lényegesen magasabb a késő antik-mediterrán jellegú tárgyak aránya, mint az Alföldön. ${ }^{17}$ Bierbrauer helyesen állapította meg, hogy a fenékpusztai eród déli kapujától nyugatra, a Keszthely-kultúra korai szakaszára keltezhető temető keleti szélén olyan temetkezések találhatók, amelyekben előfordulnak kiskosaras függők és stílustúk, de kora avar kori leletek nem, tehát ezek a temetkezések 568 előtt keletkeztek. ${ }^{18}$ Ezekbe a sírokba valóban a helyben tovább élő antik népesség tagjait temették. De a temető középső és nyugati részén ezek a tárgyak kora avar koriakkal együtt fordulnak elő, és a temető itt jelentősen kiszélesedik. Tehát az 5. század második felére és a 6. század első két harmadára, mintegy 100-120 évre keltezhetó sírok száma lényegesen alacsonyabb, mint a 6. század utolsó és a 7. század elsó harmadára - körülbelül 60-80 évre - keltezhető temetkezéseké. ${ }^{19}$ Ennek csak egy magyarázata lehet, hogy a kora avar korban jelentősen megnőtt az ide temetkező közösség létszáma. Arra több megoldás született, hogy ez mivel magyarázható. Bóna István elképzelésével, hogy itt az avarok által behurcolt hadifoglyokról van szó, ${ }^{20}$ magam sem értettem egyet, ${ }^{21}$ Bálint Csanád igazolta, hogy a hadifoglyok 618-619ben történt betelepítése túlságosan késői időpont a Keszthely-kultúra kezdetének. ${ }^{22}$ Vida Tivadar szerint a kelet-mediterrán emlékanyag betelepült, bizánci csoportokkal, a nyugat-mediterrán leletek a helyben tovább élő őslakossággal hozhatók kapcsolatba, és ez utóbbi alkotta a népesség többségét. ${ }^{23} \mathrm{~A}$ Keszthely-kultúra nem határozható meg kizárólag a kosaras függókkel, a stílustúkkel, a korongfibulákkal és a kígyófejes karperecekkel. A 6-7. századi típusok széles körú elterjedése miatt korábban magam is úgy véltem,

\footnotetext{
15 KISS 1968; TÓTH 1994; BIERBRAUER 2004.

16 VIDA 2016, 95; VIDA 2018, 228-236.

17 Ezt nevezi a kutatás „Dunántúl-jelenség”-nek (BÁLINT 1993, 245; DAIM 2003, 469).

18 BiERBRAUER 2004, 71-73. Továbbá Barkóczi már korábban bebizonyította, hogy az astragalos díszú túkkel már a 4. századtól kezdődően számolni kell (BARKóczi 1994, 110-128).

19 MÜller 2010, 243-244.

20 BÓNA 1970, 257-258, 122. jegyzet; BÓNA 1971, 294-297.

21 MÜLLER 1987, 109-110.

22 BÁLINT 1993, 226-231.

23 VIDA 2009, 244-245; VIDA 2018, 249
} 
hogy a korai fázisra nem lehet érvényes a Keszthely-kultúra elnevezés, ${ }^{24}$ ez csak a késői fázist illeti meg, mert a 7. század közepétól megjelenó, egyre nagyobb méretú, kosaras függők, az egyre hosszabb, hasított szárú ruhatúk és a kígyófejes karperecek valóban, kizárólag csak Keszthely környékéról ismertek. A közelmúltban Heinrich-Tamáska Orsolya is ezt az álláspontot képviselte. ${ }^{25}$ Legutóbb úgy fogalmazott, hogy „Ebből egyébként az következik, hogy a 7. század közepéig, tehát az ún. korai fázisra a 'Keszthely kultúra' fogalmát nem kellene használni, ezáltal összekapcsolása az 568-as évvel értelmét veszíti". ${ }^{26}$ Hasonló nézeteket vallott Blay Adrienn is: „...meg kell mutatni, hogy a fogalom a kutatás jelen állása szerint inkább terhet jelent". 27 Téves lelőhelylisták is közrejátszottak abban, hogy a Keszthely-kultúra fogalmát idejétmúltnak tekintette. ${ }^{28}$ Mindketten a Keszthely-kultúra hagyományos értelmezéséből indultak ki, hogy erre a kultúrára a kosaras függők, a ruhatúk, a korongfibulák és a kígyófejes karperecek a jellemzőek, és ezek elterjedéséból vontak le következtetéseket. ${ }^{29}$ Úgy vélem, a probléma ennél lényegesen bonyolultabb. A kérdés eldöntéséhez, hogy valóban számolnunk kell-e Keszthely és környékén a kora avar korban a Keszthely-kultúra korai fázisával, valamennyi

24 MÜller 1989, 69; MÜller 1996a, 100.

25 HeINRICH-TAMÁSKA 2008, 442-443; HEINRICH-TAMÁSKA 2016, 133-134.

26 HEINRICH-TAMÁSKA-SYRBE 2016, 27: "Daraus ergibt sich allerdingst, dass bis zur Mitte des 7. Jahrhunderts, also für die sog. frühe Phase, der Begriff "Keszthely-Kultur" nicht verwendet werden sollte und somit eine Verknüpfung mit dem Jahr 568 ihren Sinn verliert."

27 Blay 2018, 167: „Es muss gezeigt werden, dass der Begriff bei heutigem Forschungsstand eher eine Belastung dastellt."

28 Pl. a 6. század végére - a 7. század elejére keltezhető kosaras függők listája tartalmazza az 5. századra keltezhető mözsi, és a 7. század közepén megnyitott lesencetomaji temető kosaras függőit. A tévedéseket részletesen tárgyalja MüLLER 2019a.

29 Heinrich-Tamáska O. négy csoportra osztotta a Keszthely kultúra lelóhelyeit (HEINRICH-TAMÁSKA 2008, 438-439). Az I. csoportba az 568 és a 9. század elejéig használt temetők tartoznak: Keszthely-Dobogó, Alsópáhok (Hévíz) és GyenesdiásDöngeleg. A valóságban az alsópáhoki temető a III-IV. csoportba tartozik, viszont ide kell sorolni a Kéthely-Melegoldal-i temetőt. A II. csoportba (568-630/670) tartozó lelóhelyek: Keszthely-Fenékpuszta bazilika, Keszthely-Fenékpuszta horreum, Keszthely-Fenékpuszta D-i erődfal előtti temető Kimaradtak a szigligeti sírok. A Keszthely-Fenékpuszta, Pusztaszentegyházi dúlői temetőben ugyan a korai Keszthely kultúra leleteit tartalmazták a női sírok, de azt a fegyverek miatt nem sorolta ide, amint a Keszthely Fenéki úti sírokat a kosaras függők, a ruhatúk és a korongfibulák hiánya miatt. Blay A. is eldöntendő kérdésnek tartotta, hogy a Pusztaszentegyházi dúlői temető a Keszthely kultúrához sorolható-e, de egyértelmúen oda sorolta a tisztán langobárd vörsi temetőt, és a sem kosaras függőket, sem ruhatút, sem korongfibulát nem tartalmazó Keszthely-Fenéki úti temetőt (BLAY 2018, 171-173). érintett temető valamennyi leletét figyelembe kell venni. Jelen ismereteink szerint a Keszthelykultúra korai fázisának leleteit az alábbi, Keszthely környéki lelőhelyekről ismerjük (7. kép 10).

\section{Keszthely-Fenékpuszta, Lipp-féle temetó}

Tekintve, hogy a temetó a híres fenéki ménes kifutója alatt helyezkedett el, a feltárásra csak télen, 1885. január 8. és február 11. között kerülhetett sor. Bár az ásató úgy vélte, hogy a temetó az erődön belül helyezkedett el, Csák Ârpád tisztázta, hogy az eródön kívül, a DNy-i saroktoronytól mintegy $100 \mathrm{~m}$-re folyt az ásatás. ${ }^{30} \mathrm{~A}$ temető nem része a közvetlenül a déli erődfal előtt lévő temetônek, attól D-re található. ${ }^{31}$ Lipp öszszesen 300 sírt tárt fel, ebből 209 kóból falazott vagy téglasír volt, 91 pedig építmény nélküli sír. Döntô többségükben késó római temetkezések, melyek nagy részét már kirabolták. A leleteket 1886-ban tette közzé, ${ }^{32}$ az irodalma óriási. ${ }^{33}$ Eredményeinek ellenőrzését és értékelését megnehezíti, hogy feltehetóen már Lippnél összekeveredett a fenékpusztai anyag a vele csaknem egy időben feltárt páhoki (hévízi) temetó anyagával. A két temetô tárgyait két részletben - 1885 . április 15-én és 1885. november 21-én - adta el a Nemzeti Múzeumnak. Ott egymást követő leltári számokat kaptak (30/1885, 31/1885, ill. 146/1885, 147/1885). A feldolgozás során Lipp rájött, hogy tévedett, és a publikációban igyekezett ezt korrigálni. Tábláin nemcsak páhokiként beleltározott tárgyakat közölt fenékiként, hanem Páhokon (Hévízen) előkerült késő avar koriakat fenékiként. ${ }^{34}$ Csak öt sír leletanyagát ismertette külön. Ebből 3 préselt, soktagú övgarnitúrát tartalmazott (Bóna I-III. sír). ${ }^{35} \mathrm{Az}$ I. sírban volt az ún. Keszthely-fenékpusztai típusú szíjvég (1. kép 1), amelyen két ellentett állású szakállas fej közötti körben egyenlőszárú kereszt látható, amelynek szinkretisztikus, illetve primer keresztény jelentést tulajdonítanak. ${ }^{36}$ Bóna feltételezte, hogy

30 CsÁK 1903, 24. kép; MÜller 2012, 37.

31 MÜLLER 2010, 153-156.

32 LIPP 1886.

33 Jó áttekintés ad a korai irodalomról CSALLÁNY 1956, 136, 447; BAKAY-KALICZ-SÁGI 1966, 86-87. 21/33. lh.

34 MÜLLER 2012.

35 BÓNA 1982-83, 117-119. Az irodalomban mindig ezüst övgarnitúrákról van szó, de csak az I. sír nagyszíjvége készült ezüstból, a többi veret bronzból (MÜLLER 2010, 13-15).

36 NAGY M. 2002, 158; WAMERS 2008, 61-63 (utóbbi tévesen közép avar korinak tartja ezt a verettípust). A szíjvéggel foglalkozott Bálint Csanád is (BÁLINT 2019, 55). Az elterjedési térképe (BÁLINT 2019, Fig. 22, 4) jó, E. Wamers hivatkozott térképe rossz, a Dunakanyarban túl sok a lelóhely, a Tolna megyeiek viszont hiányoznak (WAMERs 2008, Abb. 30, 3). 


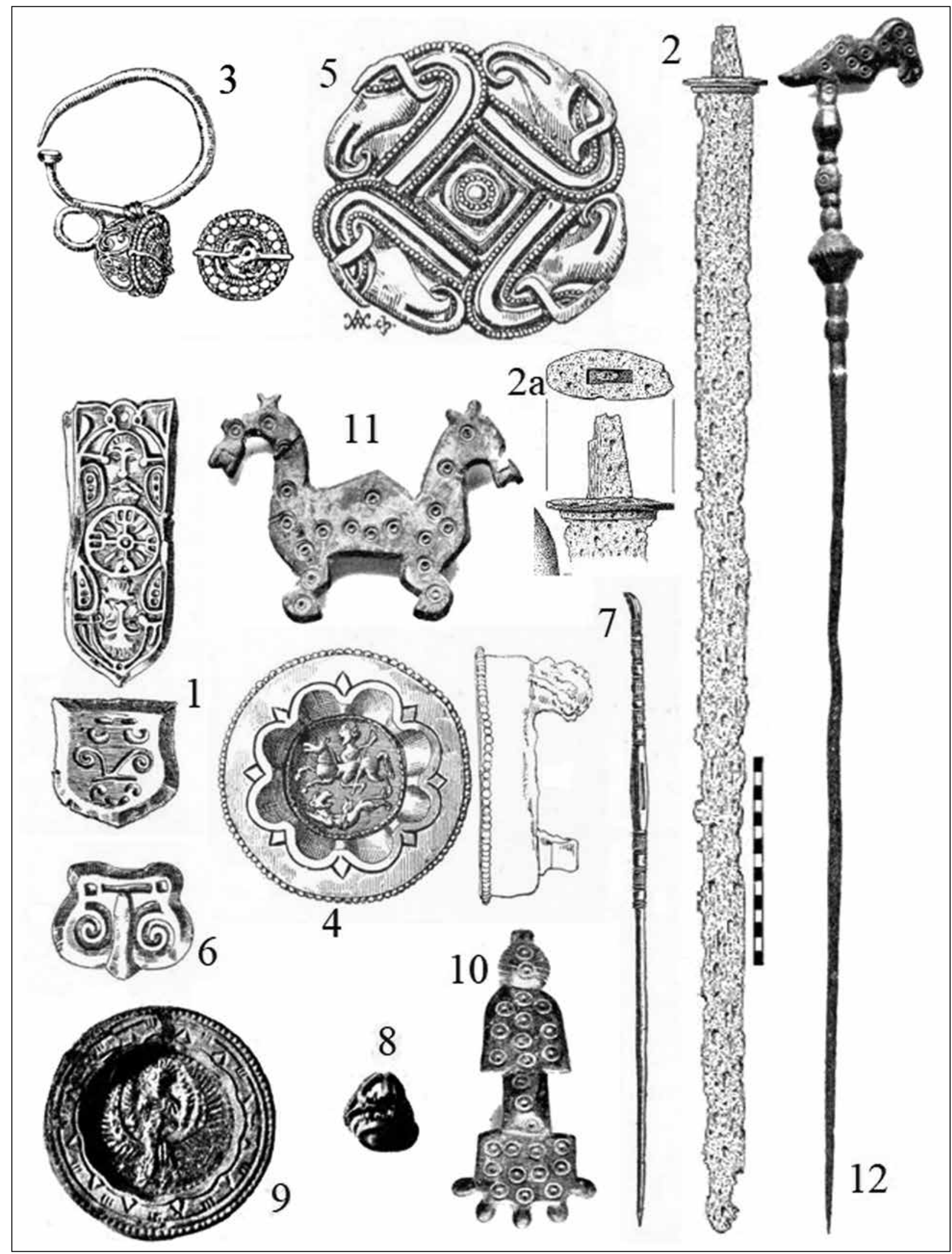

1. kép. 1-7: Keszthely-Fenékpuszta, Lipp-féle temető; 8-12: Keszthely-Fenékpuszta, Csák-féle temető. Különböző léptékek Fig. 1. 1-7: Keszthely-Fenékpuszta, cemetery excavated by Vilmos Lipp; 8-12: Keszthely-Fenékpuszta, cemetery excavated by Árpád Csák. Various scales 
ugyanebben a sírban volt egy kétélú kard is (1. kép 2-2a), amit tévesen sztyeppei eredetünek vélt, ${ }^{37}$ holott az inkább egy germán spatha. ${ }^{38}$ Egy késő császárkori nói sírban (IV.) ládikaveretek is voltak, az V. sírba temetett nó mellékletei - arany kosárkás függó (1. kép 3), Bellerophont és a Khimairát ábrázoló ezüst korongfibula (1. kép 4), stilizált, rekeszdíszes állatfejben végződő karperec - csak a horreumi temető női sírjaival vethető össze. ${ }^{39}$ További előkelő nói sír(ok)ra utal egy további, aranykosaras függő, ${ }^{40}$ egy Pannoniában egyedülálló madárfej-koszorús (négy kampós csőrú madárfejet ábrázoló), aranyozott ezüst korongfibula (1. kép 5), ${ }^{41}$ és egy szép kétsoros csontfésú. ${ }^{42}$ Azt nem tudjuk, hogy a gazdag sírok közelében voltak-e melléklet nélküli sírok, mint a horreumnál, de a horreumtól eltérően, köznépi temetkezések igen. Erre utalnak az egyszerú, bronzból öntött kosaras függő és a bronz ruhatúk. ${ }^{43}$ Ebbe a kisebb temetóbe, amelynek Lipp feltehetően csak egy részét tárta fel, gazdag nóket, préselt álcsatos (1. kép 6) és Martinovkatípusú övgarnitúrát, esetenként fegyvert is viselő férfiakat és szegényesebb mellékletú köznépi személyeket temettek. A mellékletek alapján a temetőt a 6. század utolsó és a 7. század első harmadában használták.

\section{Keszthely-Fenékpuszta, Csák-féle temető}

16 évvel Lipp után Csák Árpád a Balatoni Múzeum Egyesület régészeti gyújteményének őre folytatta a temetőfeltárást Fenékpusztán. Az általa feltárt temetőrészből is döntően késő császárkori temetkezések ismertek, de előfordulnak a 6. század végére, a 7 . század elejére keltezhetó sírok is, ezért a korábbi kutatás a Lipp- és a Csákféle feltárást ugyanazon temető két részletének gondolta. ${ }^{44}$ Csák pontosan tudta, hogy Lipp hol ásott, hiszen a Lipp által betanított Sirsom testvérekkel dolgoztatott ó is. Tekintve, hogy Lipp szerint ő megtalálta a temető D-i és K-i szélét, Csák pedig Lipp temetójétől mintegy 185 m-re K-re ásatott, ez egy külön temető volt. Az általa közölt térkép ${ }^{45}$ alapján az erőd D-i falától távolabb, mintegy $100 \mathrm{~m}$-re, az erődből kivezetô út K-i oldalán folyt a feltárás. ${ }^{46} \mathrm{Ez}$ is még a ménes kifutójának területére esett, így a feltárásra 1901. január 28. és március 30 . között került sor. A korábbi irodalom szerint Csák 150 sírt tárt fel.$^{47} \mathrm{Az}$ utólag előkerült ásatási napló 133 sír adatait tartalmazza, de bizonyíthatóan két sír leírását ez nem tartalmazza, ${ }^{48}$ így 135 sírral számolhatunk. ${ }^{49}$ A temetó értékelését megnehezíti, hogy a Kuzsinszky által ismertetett 48 sír $^{50}$ csak részben azonosítható a múzeum leltárkönyvében szereplő 48 sír anyagával, és az ásatási napló adataival. A leletek egy része a II. világháború végén megsemmisült. A megmaradt 26 síregyüttest - kivétel nélkül késő császárkori temetkezések - Pekáry Tamás tette közzé. ${ }^{51}$ Ezek a 4. század második felére és az 5. század elejére keltezhetők. A 135 sírból 74 tartalmazott mellékletet, közülük 35 volt téglasír. A temetkezések döntően késő császárkoriak, de itt is voltak kora avar kori temetkezések. Már Pekáry felismerte, hogy Alföldi tévedett, a temetkezések nem folyamatosak, a késő császárkori temetó felhagyása után a 7 . században rátemetkeztek a korábbi sírokra. ${ }^{52}$ Legalább öt női vagy leánysír keltezhető a 6 . század végére és a 7. század elejére. A leggazdagabb ezüstból készült, áttört kosárkás függőpárt (1. kép 7), császár apoteózist ábrázoló, aranyozott képmezőjú, ezüstból készült korongfibulát (1. kép 8), szemesgyöngyöket és három bronz karperecet tartalmazott. Egy másikban kis méretú, bronzból öntött, pontkörökkel díszített kengyelfibula (1. kép 9), a harmadikban ugyancsak pontkör díszítésú kettős lófibula (1. kép 10), a negyedikben bronzból készült karperec, gyưrú, "gombos fülkarika” - nyilvánvalóan öntött kosaras fülbevaló - és fülkanalas ruhatú volt. Az ötödik sírból csak a hatalmas, kampós csőrú, ugyancsak pontkörökkel díszített tú ismert (1. kép 11). A sírok a napló szerint egymás közelében kerültek elő. A nőkhöz tartozó férfisírokat nem ismerjük. A sírcsoport közelében volt olyan férfisír, amely csak egy

45 CSÁK 1903, 24. kép.

46 MÜLLER 2010, Verbreitunskarte 1, II. temető.

47 KuZSINSZKY 1920, 70; BAKAY-KALICZ-SÁGI 1966, 86, 21/33. lh.

48 A Kuzsinszky által ismertetett 11. sír, egy téglasír, amelyből ép üvegedény, hordó alakú aranygyöngyök, gyưrú és csontból készült guzsaly került elő (KUZSINSZKY 1920, 73), nem szerepel az ásatási naplóban. Akárcsak egy hosszú, pontkör díszítésú tú, amelyről azt írta Hampel, hogy „a közelmúltban folytatott feltárás során találták Fenékpusztán" (HAMPEL 1905, I, 384, Abb. 1046 és II, 705).

49 MÜller 2010, 20-32; MÜlLer 2012, 52-58.

50 KUZSINSZKY 1920, 70-74.

51 PEKÁRY 1955.

52 PeKÁRY 1955, 29. 


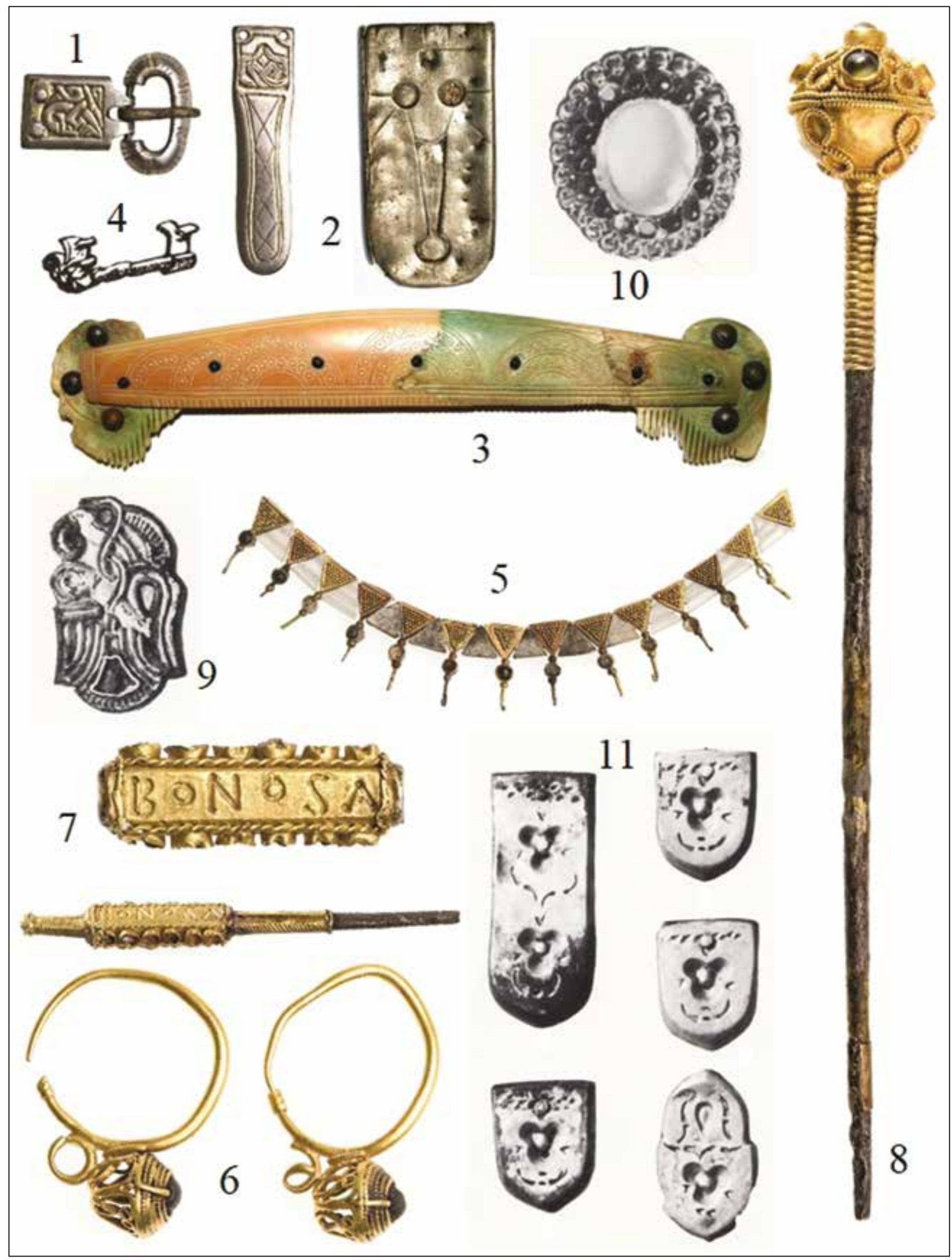

2. kép. 1-4: Keszthely-Fenékpuszta, ókeresztény bazilika; 5-11: Keszthely-Fenékpuszta, horreumi temető. Különböző léptékek

Fig. 2. 1-4: Keszthely-Fenékpuszta, early Christian basilica; 5-11: Keszthely-Fenékpuszta, horreum cemetery. Various scales 
vascsatot tartalmazott, de lehettek melléklet nélküliek, ami gyakori a Keszthely-kultúra temetőiben. A korongfibula, a kosárkás függők, a ruhatú alapján ez a temetórészlet egyidős a Lipp-féle temetôrésszel, de egészen más jellegú: szegényebb, nincsenek benne aranytárgyak, övgarnitúrák, fegyverek, viszont jellegzetes díszítésmód az öntött tárgyakon a pontkör.

\section{Keszthely-Fenékpuszta, ókeresztény bazilika}

A háromhajós, három apszissal záródó épület egy részét Csák tárta fel 1907-1908 fordulóján, és fürdőként határozta meg. Kuzsinszky nem említi. ${ }^{53}$ Nagy Lajos határozta meg ókeresztény bazilikaként, és a 2. számot adta neki. ${ }^{54}$ Feltárását 1947-ben folytatták, majd 1959-ben Sági Károly fejezte be. ${ }^{55}$ Négy építési periódust határozott meg, az épületet szerinte a 4 . század végétől a magyar honfoglalásig használták keresztény kultuszhelyként. Ma a kutatás úgy véli, hogy használata 630 táján, miután felgyújtották, megszúnt. ${ }^{56} \mathrm{Az}$ épületen belül, a mellékhajókban kilenc, az épülettől D-re pedig két sír került elő. ${ }^{57}$ A bazilikán belüli 9 sírból öt kőpakolásos volt. Ezt a temetkezési szokást a horreumi és a D-i erdőfal előtti temetőből is ismerjük. A sírok többsége bolygatott, illetve rablott volt. A három bolygatatlan sír nem tartalmazott mellékletet. A kirabolt 3. sírból II. germán állatstílussal díszített, kis méretú, aranyozott ezüstcsat és szijvég került elő (2. kép 1). Ezt korábban cipőcsatnak, mások lábszárszíjnak (Wadenbindengarnitur) vélték. ${ }^{59} \mathrm{Az}$ ásató a halott neméről nem nyilatkozott, de a többi lelet és a hosszúcsontok mérete alapján egyértelmú, hogy a 3. sírba férfit temettek, ezért feltehetôen nem lábszárszíjhoz tartozott, hanem egy tarsoly zárására szolgált a csat és a szíjvég. Előkerült még egy Martinovka-típusú, áttört díszú, ezüst nagyszíjvég (2. kép 2), egy egysoros, szépen díszített csontfésú fatokban (2. kép 3), egy vasolló és egy kopott Valens-érem. A 6. sírba egy nót temethettek, mert a rablott sír földjéból egy kis méretú, nyéltüskés vaskés mellett egy ezüst-

\footnotetext{
53 KUZSINSZKY 1920, mert a kéziratát 1906-ban lezárta.

54 NAGY L. 1938, 79.

55 SÁGI 1961.

56 TÓTH 1987, 254-261; MÜller 1987, 112-114; HeINRICHTAMÁSKA 2010, 101-106.

57 A bazilikától D-re talált melléklet nélküli sírok feltehetően korábbiak. Az 1. sírt hat faragott kólapból állították össze, tetejét háztetőszerúen alkotta két kőlap, feltehetően késő császárkori. A 2. sír részben a bazilika DK-i sarkához épített kis kápolna fala alá nyúlt, tehát annál korábbi.

58 MÜlLER 2002, 33.

59 HeINRICH-TAMÁSKA 2010, 110; VIDA 2018, 522.
}

ből készült korongfibula túszerkezete került eló (2. kép 4). Sági helyesen keltezte a sírokat 568 és 630 közé. ${ }^{60}$

\section{A Keszthely-Fenékpuszta horreumi temetó}

Az erőd K-i kapuja közelében, a horreum K-i oldalán 1959-ben Barkóczi László 31 bolygatatlan sírból álló temetót tárt fel. ${ }^{61}$ Ezek egy része rendkívüli gazdag mellékleteivel túnt ki, míg 9 sír melléklet nélküli volt. ${ }^{62} \mathrm{~A}$ temetőtől K-re, kissé távolabb 1970-ben Horváth László további 8 sírt talált, ebból legalább három ehhez a temetóhöz tartozott. ${ }^{63}$ A sírok Ny-K tájolásúak és öt kivételével kőpakolásosak. A női sírokból a következő viseleti tárgyak emelhetók ki. Pannoniában egyedülállók a hajhálót díszítő vékony aranycsövecskék (8., 9., 14. és 17. sír; 3. kép 1), illetve a háromszög alakú csontlapocskákból és ugyanilyen, granulációval díszített, aranyfoglalatokból és gránátbetétes csüngőkkel ellátott gallérdísz (5. sír; 2. kép 5). ${ }^{64}$ Arany kosárkás függők: négy áttört kosárkás (6., 9., 17., 29. sír; 2. kép 6); Allachtípusú, virágkehely alakú kosárka (8. sír); félhold alakú csüngődíszes függő (5. sír); bronz, gúlacsüngős függő (18. sír). Túk: arany, négyszögletes, hasáb alakú taggal díszített tú, rekeszekbe foglalt ékkövekkel és BONOSA felirattal (5. sír; 2. kép 7); egyszerúbb, ezüst változatán nincsenek ékkövek, csak áttört (30. sír), ékkövekkel díszített, arany, gömbben végződő tú (6. sír; 2. kép 8); aranyozott bronz és bronz astragalos díszú tú (14. és 37. sír); a 25. sírban pedig vastú volt. Fibulák: germán, kőberakásos, aranyozott sas- ${ }^{65}$

60 HeINRICH-TAMÁSKA 2010, 111. a tárgyakat a 6. század középső harmadára, ill. tág határok között a 6 . század második és a 7. század első felére keltezte.

61 BARKÓCZI 1968; BARKÓCZI 1971.

62 VIDA 2011, Abb. 1. csak 6 melléklet nélküli sírt jelzett.

63 STRAub 1999, 198 négy sírt $(34,35,38,39)$ késő római korinak határozott meg. Vida T. szerint csak a 34-35. és a 38. keltezhető a 4. századra (VIDA 2011, 398, Abb 1). Véleményem szerint a sírforma, a csontmaradványok állapota és a mellékletek alapján három sír $(32,33,37)$ tartozhatott a horreumi temetóhöz. Straub P. és Vida T. a 36. sírt is oda sorolta. Ennek ellentmond, hogy ez a sír K-Ny tájolású - a Straub által említett bazilikai 8. sírról nem írja Sági K., hogy K-Ny tájolású volt, és a Taf. XI, 2 alapján ez is Ny-K irányítású lehetett (SÁGI 1961, 420) - alját eredetileg tegulákkal rakták ki, ellentétben a többi sírral, ez rablott volt. Az ovális vascsat lehetne akár római kori is, de az egyoldalas fésú idegen a késő császárkori leletanyagban. Ez germán tárgy, bár vannak olyan íves hátú fésűk, amelyeknél a külső csontléc egy lemez. Pl. Solva, 212. sír (H. KELEMEN 2008, 48. t. 212/9 és XXVI. t. 89).

64 GARAM 1991.

65 A 4. sír sas fibulájának kapcsolatát a Jankovich-aranyak vadkan veretével már többen hangsúlyozták (HEINRICH-TAMÁSKA 2006a, 62 tévedésből a 17. sír fibulájának katalógusszámát 
illetve S-fibulák (4., 11., 17. és 32. sír; 2. kép 9); hegyikristállyal, gránáttal és igazgyönggyel díszített, arany korongfibula (8. sír; 2. kép 10); filigránnal díszített, arany dobozfibula (9. sír); három dobozos korongfibula kerete ezüstlemez, a bemélyített képmező aranyozott és ókeresztény jeleneteket ábrázol (5., 12. és 14. sír; 3. kép 2);66 fogazott díszú, ezüst lófibula (17. sír; 3. kép 3). Gyưrúk: aranyból készült a 6. sír kopott, architektonikus gyúrúje, és a 8. sír köves gyúrúje, a négyszögletes foglalata fölé kerek foglalat emelkedik, ezüstből készültek a férfit és nőt (7. sír), a keresztet (9. sír) és a feltehetóen halat (16. sír) ábrázoló gyứrúk, az 5. sír aranyozott bronzgyúrújén feltúnik a kora avar korra jellemző fogazás. ${ }^{67}$ Említésre méltó a 8 . sírban talált aranylemezből hajlított bulla. ${ }^{68}$ A karperecek egyszerú formák, bronzból és vasból készültek. A gyöngysorok - többségük borostyánt is tartalmazott különbözőek, késő antik, kora bizánci, Rajna vidéki párhuzamokkal rendelkeznek. ${ }^{69}$ Soktagú, préselt, ezüst övgarnitúra két sírban volt, a 15. sírban egy fiú övén Fönlak-Aradka- (FelnacAradac) típusú (2. kép 11), három bemélyített félgömbbel és pont-vesszővel díszített veretek voltak, a 16. sírban egy 40-45 éves férfi övét Martinovka-típusú szíjvégek és veretek díszítették, és egy fogazott díszú bizánci csat fogta össze. ${ }^{70}$

A horreumi temetôbe - az ásató szerint - egy előkelő bizánci közösség temetkezett 546-582 között. $^{71} \mathrm{~A}$ magyar kutatás általában 568 és 630 közé keltezi ezt a temetőt. Falko Daim szélesebb határok között a 6. század második és a 7. század első felére. ${ }^{72}$ Volker Bierbrauer a temető megnyitásáról csak azt írta, hogy Fenékpuszta környéke az 5. századtól a mediterrán Romania része volt,

adta meg; VIDA 2011, 411), de érdemes felhívni a figyelmet a kampós csőr és a hangsúlyos szemöldök megegyezését a Lipp-féle temető madárfej koszorús korongfibulájával.

66 Az ókeresztény jeleneteket ábrázoló korongfibuláknak óriási az irodalma. Teljes áttekintést ad GARAM 1993 és GARAM 2001, 51-56, Taf. 31-32. Felmerült, hogy zarándok amulettek lehettek (DAIM 2002). Tartották őket import tárgyaknak és helyben gyártottaknak is (legutóbb BoLLóK 2014). Az 5. sír valószínúleg Heraklesz és Omphale történetét ábrázolja (GLASER 2002). A 12. sírban Bellerophon és a Khimaira harca látható (BOLLÓK 2014, 264-271). A 14. sírban egy kereszten Krisztus büszt, két oldalán angyal látható (VIDA 2018, 60-61).

67 HeINRICH-TAMÁSKA 2006b, 511-515. Vida T. szerint ez a fogazott díszítés a kora avar kori fogazott díszítés előzményének tekinthető (VIDA 2011, 414).

68 VIDA 2011, 407.

69 PÁszTOR 2011.

70 GARAM 2001, 115-119, 124-130; VIDA 2011, 412-413.

71 BARKÓCZI 1968, 310; BARKÓCZI 1971, 190. Később még korábbra, a 6. század első felére keltezte: BARKÓCZI-SALAMON 1984, 172 és 180.

72 DAIM 2000. és a horreumi sírok egy része bizonyosan 568 előtti, a temetőt szerinte is a 7. század első harmadáig használták. ${ }^{73}$ Vida Tivadar szerint a temetőt egy-két évtizeddel korábban, már a 6. század közepén megnyitották, ${ }^{74}$ de a temetőt az analógiáik által az 568 előttre keltező tárgyak - mint a BONOSA feliratú tú, a félhold alakú csüngős függő, a gallérdísz, a hegyikristállyal, gránáttal és igazgyöngyökkel díszített korongfibula, az architektónikus gyürú - erős kopásnyomokat mutatnak. Többségük sérült, hiányos vagy javított, ezért feltételezhető, hogy hosszabb használat után kerültek csak földbe. A gyöngysorok is a 6. század utolsó és a 7. század elsó harmadára keltezhetők. ${ }^{75}$ Ezért úgy vélem, fenntartható az 568-630 közötti időszakra történő keltezés.

\section{Keszthely-Fenékpuszta, a déli erődfal előtti temetó}

1963 és 1967 között Sági Károly a déli erődfal előtt, a DNy-i saroktorony és a D2 torony között 88, a D3 és a D4 tornyok között 11, összesen 99 sírt tárt fel. ${ }^{76}$ A leletanyag fellelhető, de dokumentáció csak az első 36 sírról áll rendelkezésre. Ebból 17 bizonyosan, 14 valószínúleg kora avar kori és 5 lehet akár késő antik is (5. század második fele, 6. század első két harmada). A nemek szerinti megoszlás kiegyensúlyozott: férfi vagy fiú 14 , nó vagy leány 12 , felnőtt 2 , ismeretlen nemú gyermek 8 . A leletanyag alapján a 99 sírból 7 késó római, 36 késő antik vagy kora avar kori és 56 bizonyosan vagy valószínúleg kora avar kori. 1970-ben Horváth László a D4 torony átvágásakor annak külső oldalán 7, 1971-ben Horváth László és Müller Róbert a D4 torony és a D-i erődkapu közötti területen 120 temetkezést tárt fel. ${ }^{77}$ Ezek közül a mellékleteik alapján legalább 11 temetkezést - 9 női és két férfisírt - tévesen a korai Keszthely-kultúrához tartozóként közöltem. ${ }^{78}$ A sírok keltezését megnehezíti, hogy azok csaknem fele (56) melléklet nélküli volt. A mellékletek alapján pedig négy időszakban használták a temetôt: 18 a késó császárkori (4. század közepe - 5. század közepe), 9 bizonyosan késő antik (5. század közepe - 6. század első két harmada), 1 korai Keszthely kultúra (6. század

73 BIERBRAUER 2004, 73.

74 VIDA 2011, 413-414.

75 PÁSZTOR 2011.

76 MÜller 1999; MÜLler 2010, 48-61.

77 Csak 118 sír tartozik a D-i fal előtti temetőhöz, mert két melléklet nélküli gyermeksír (1971/4 és 28) az erődfal belsó oldalán került elő

78 MÜLler 1987, 110-113; MÜLLER 1992, 263. 
utolsó harmada - 7. század első harmada) ${ }^{79}$ és 39 a Karoling-kori (9. század második fele). Ezenkívül 8 sír késő római vagy késő antik, 34 sír melléklet nélküli, rossz fenntartású vázakkal, részben kőpakolással, ami a késő antik és a kora avar kori temetkezésekre jellemző. 16 melléklet nélküli váz keltezhetetlen. 1976-ban az 1. munkahelyen, a D1 torony K-i oldalán Erdélyi István 29 sírt, 1980-ban a D1 torony Ny-i felének feltárása során Tóth Endre a torony külső oldalán egy sírt tárt fel. ${ }^{80}$ A 30 sírból 12 volt melléklet nélküli. Férfi vagy fiú 8 , nő vagy leány 14 , felnőtt 2 , újszülött vagy gyermek 7.8120 sír biztosan vagy valószínúleg kora avar kori, 8 lehetne akár késő antik is, 2 keltezhetetlen. 1980-ban a 13. munkahelyen, a D3-D4 torony között és a D4 előtt Müller Róbert 27 sírt tárt fel. ${ }^{82}$ Figyelembe véve egy kettős sírt férfi vagy fiú 6 , nő vagy leány 13, felnőtt 3, újszülött vagy gyermek 6.5 temetkezés késő római, 4 késő antik, 13 kora avar kori, 3 Karoling-kori, 2 nem keltezhető. 1992-ben optikai kábelt fektettek a D-i erődfal előtt. Az alig 40 cm széles árok oldala elkenődött, így csak 3 sír átvágását tudtuk megfigyelni: 1 késő római, 1 kora avar kori és 1 Karoling-kori. ${ }^{83}$

1999-2000-ben lehetőségünk nyílt az erőd D-i fala előtti temetők kiterjedésének meghatározására. A D1 toronynál nyitott É-D irányú 8-9. árokban az erődfaltól 39 m-re volt a legtávolabbi sír, és az erődfaltól 77 m-re még nem értük el a Lipp-féle temetőt. A D-i kapu előtt a 10. árokban 25 m-re volt a D-i faltól a legtávolabbi sír, az ún. II. temető szélső sírját 110 m-re értük el. A Csák-féle temetó ettól K-re helyezkedik el. ${ }^{84}$ $\mathrm{Az}$ 1-7. árok a közvetlenül az erődfal előtti temetőn haladt át. A D1-D3 tornyok körzetében 63 sír került feltárásra. Ebből 24 volt melléklet nélküli. Kor szerinti megoszlásuk: késő római 2, késő római vagy késő antik 1 , a mellékletek, a vázak fenntartása vagy a kőpakolás alapján bizonyosan vagy valószínúleg 60 kora avar kori. Nemek szerinti megoszlásul: 16 férfi vagy fiú, 35 nő vagy leány, 3 felnőtt és 9 gyermek. ${ }^{85} \mathrm{Az}$ 5. árokban a D-i erődkapu előtt 14 sírt tártunk fel.

79 A D4 torony előtt az 1970/4. sírban egy gúlacsüngős függő volt.

80 Straub 1999; Straub 2000. Az 1980/1. sírnak csak kisebb részét tárták fel, így nem értékelhető.

81 A korai Keszthely-kultúrában a férfisírok gyakran melléklet nélküliek, a felnőtt és a nem nélküli sírok többségébe bizonyára férfit, illetve fiút temethettek.

82 MÜLLER 2010, 104-108.

83 MÜLLER 2010, 109.

84 MÜLLER 2010, Taf. 81, Verbreitungskarte 1-2.

85 Ha az összes felnőttet és gyermeket férfinak, ill. fiúnak tartjuk, akkor is csak 28 a számuk a 35 nővel és leánnyal szemben. A többi temetőrészletnél kiegyensúlyozottabb volt a nemek aránya.
4 volt melléklet nélküli, egy késő római, 4 késő római vagy késő antik, 7 Karoling-kori és 2 keltezhetetlen. ${ }^{86}$ A D-i erődfal előtt, a D-i erődkaputól Ny-ra tehát összesen 346 sírt ismerünk eddig. Ebből 9 a késő római vagy késő antik, 13 a nagy valószínúséggel késő antik, 70 a késő antik vagy kora avar kori és 151 bizonyosan vagy nagy valószínúséggel kora avar kori. A temetkezést közvetlenül az erődfal előtt a 4 . század közepén kezdték el, szórványosan a fal teljes hosszában vannak késő római kori sírok. Az 5. század közepétól csak a D-i kaputól Ny-ra, a D4-D5 torony között temetkeztek, itt megfigyelhető a kontinuitás. Itt a legmagasabb a melléklet nélküli sírok aránya, és a lemezes kosárkás függők és a ruhatúk mellett nincsenek kora avar kori leletek. A legkeletibb 568 utánra keltezhetó sír a D4 torony elött került elö. ${ }^{87} \mathrm{~A}$ késó antik temetó folytatásaként a D4 torony és a DNy-i saroktorony közötti részre döntóen 568 és 630 között temetkeztek, a legkésőbbi sír a 7. század közepére keltezhető. Ezután csaknem két évszázados hiátus következett, majd a 9. század közepétől a Karoling-kori temetó a D-i erdőkapu két oldalán helyezkedett el. ${ }^{88}$

A legjellemzőbb leletek a következők: lemezes (3. kép 4) vagy öntött (3. kép 5) bronz kosaras függők, áttört ezüst kosarú csak egy sírban volt, fóleg a korai temetkezésekben poliéder végú függők, öntött, gömbcsüngős vagy gúlacsüngős függók (3. kép 6), egyszerú vas-, astragalos díszú, baltában (3. kép 7) vagy madárban (3. kép 8) végződő bronztúk. Fibulából viszonylag keveset ismerünk, korongfibulából csak egy poncolt díszú, ezüst példány került elő (3. kép 9), de van pontkörrel és félkörökkel díszített, svasztikás fibula (3. kép 10), aláhajtott lábú fibula, fonott, keresztmintás lemezfibula (4. kép 1), sőt egy korábbi germán kengyelfibulát is találtunk (3. kép 12). Nagyon változatosak a gyöngysorok. ${ }^{89}$ A legegyszerúbb öveket csak egy vas- vagy bronzcsat fogta össze, ezek egy részén pajzsos vagy megvastagodó tövis van. Egy háromszög veretú, félkörökkel díszített bronzcsathoz ellenveret is tartozott. A veretes övek között vannak Martinovkatípusú garnitúrák, gyöngysor keretezésú préselt veretek, itáliai (alpi) övgarnitúra (3. kép 11) és germán, rekeszes díszú vasveretek (4. kép 2). A legkésóbbiek a pajzs alakú betétdíszes veretek. ${ }^{90}$

86 MÜller 2010, 109-152, Taf. 81.

87 Lásd a 79. lábjegyzetet.

88 MÜlLER 2010, 246-247.

89 PÁszTOR 2010.

90 Az 1963/5. sírból ezüstözött bronzveretek, a betétdísz ezüstlemez. Jó párhuzama a 7. század közepéról egy teljes garnitúra a budakalászi 696. sírból, ami ezüstlemezból készült és aranyozott a betétlemez (VIDA-PÁszTOR 1996). 


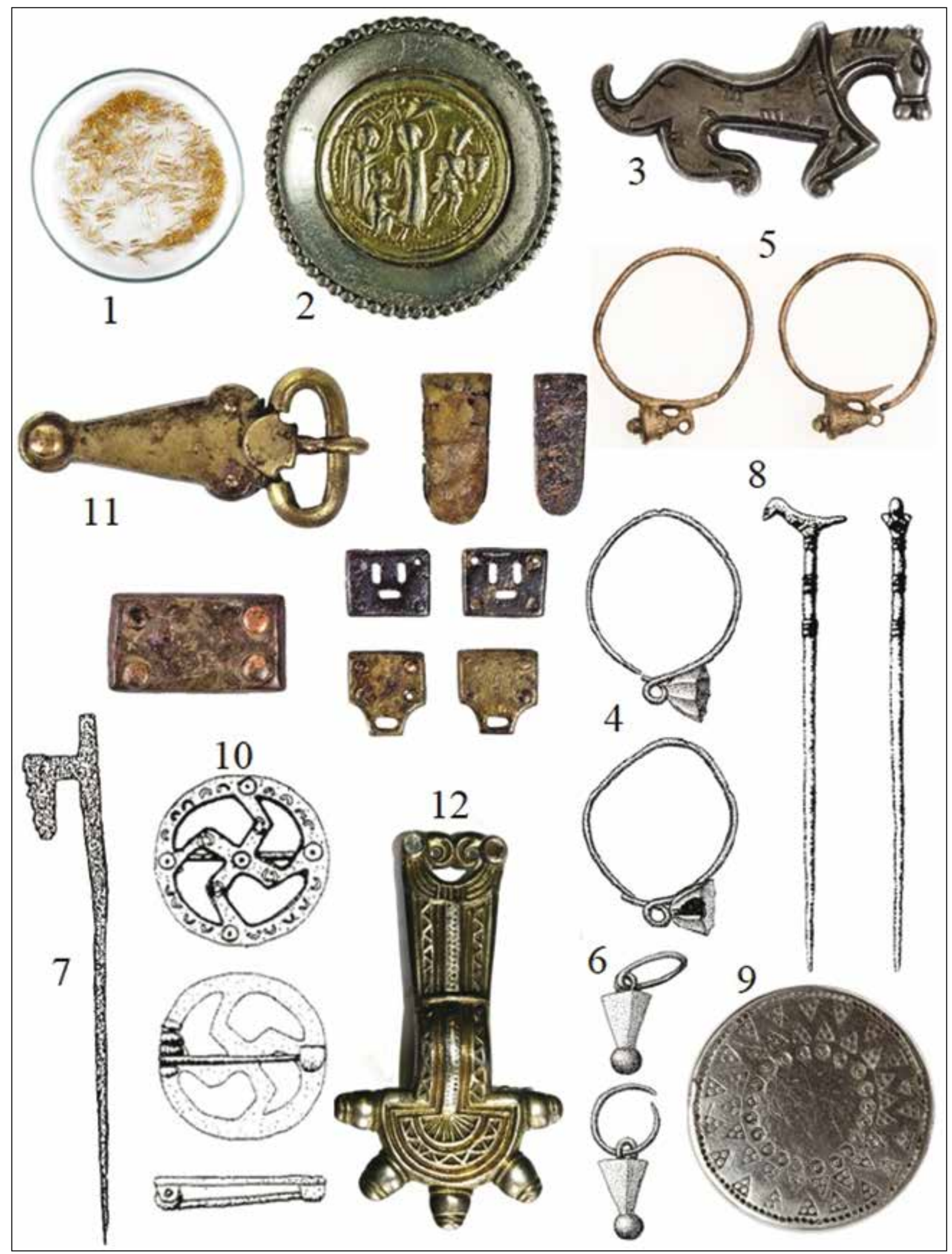

3. kép. 1-3: Keszthely-Fenékpuszta, horreumi temető; 4-12: Keszthely-Fenékpuszta, déli erődfal előtti temető. Különböző léptékek

Fig. 3. 1-3: Keszthely-Fenékpuszta, horreum cemetery; 4-12: Keszthely-Fenékpuszta, cemetery by the southern fort wall. Various scales 


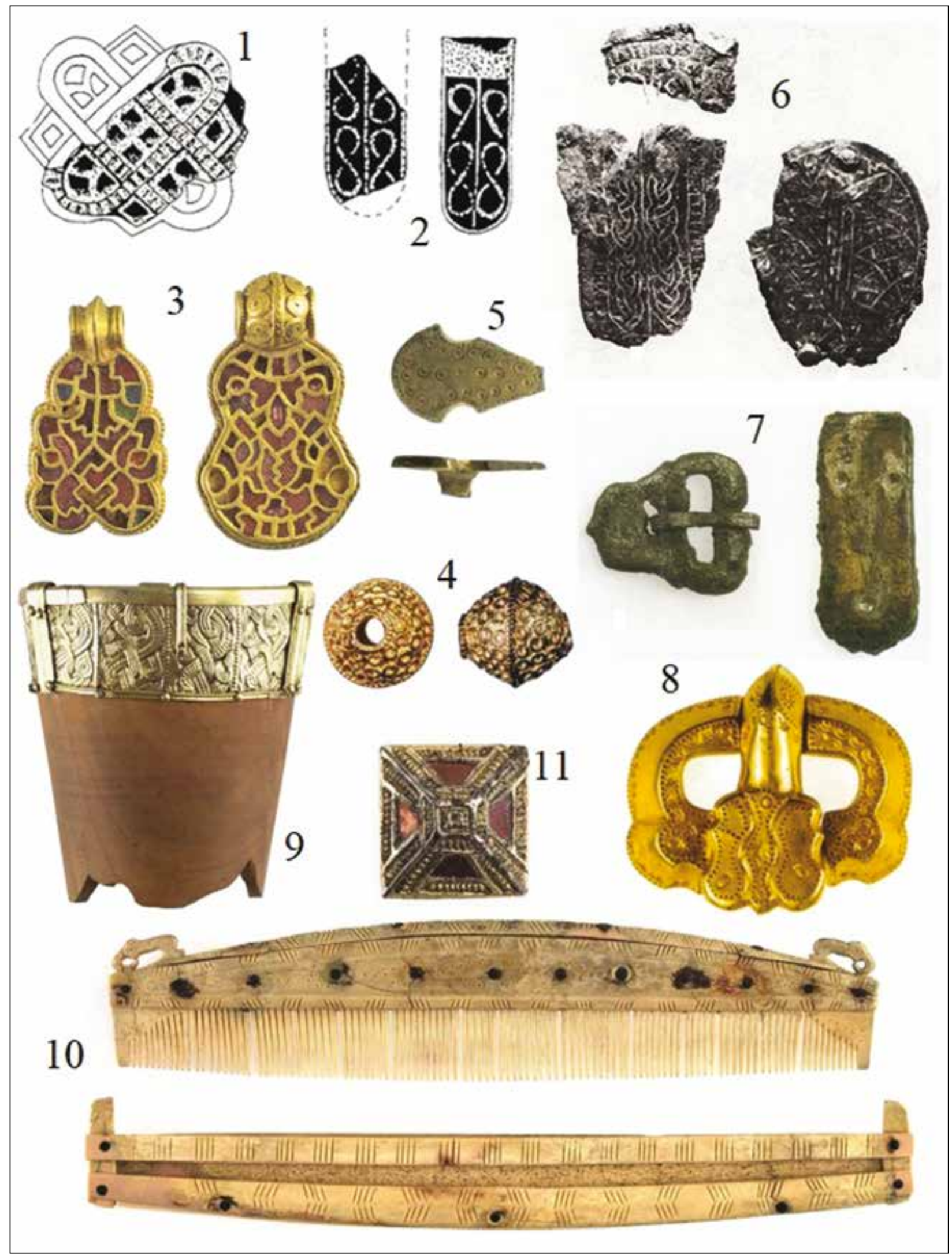

4. kép. 1-2: Keszthely-Fenékpuszta, déli erődfal előtti temető; 3-7: Keszthely-Fenéki úti temető; 8-11: Keszthely-Fenékpuszta, Pusztaszentegyházi dúlői temető. Különböző léptékek

Fig. 4. 1-2: Keszthely-Fenékpuszta, cemetery by the southern fort wall; 3-7: Keszthely-Fenéki Road cemetery; 8-11: KeszthelyFenékpuszta, Pusztaszentegyházi-dúlő cemetery. Various scales 


\section{A Keszthely-Fenéki úti temetó}

1973 februárjában Keszthelyen, a Fenéki út Ny-i oldalán, az erődtől mintegy 2 km-re, É-ra, a regionális vízvezeték árkával átvágtak két rablott sírt. A 2. sírba, amely egy 3,75 m mély kamrasír volt, egy 16-18 éves nőt temettek. A rablás ellenére számos értékes, egyedülálló tárgy került elő: a nyakláncból két cloisonné díszú aranycsüngó (4. kép 3), 2 filigrán díszes, aranygyöngy (4. kép 4), $15+3$ éremlenyomat és pasztagyöngyök, 11 poncolt díszú, lapos téglalap alakú, szegecselt, kettős veret, pontkör díszú, aranyozott bronz, pajzs alakú csatrögzítő (4. kép 5), másodlagosan felhasznált, római aranygyúrú, pontkörös csontlécekkel díszített faládika, benne tízszögletes hengeres doboz tolózárral és egyoldalas csontfésúvel, a sok aranyszál alapján egy nagyobb brokát is volt a sírban. 1974-ben Sági Károly feltárta a teljes temetőt, amely mindössze 10 sírból állt. ${ }^{91}$ A 4. sír, a másodikhoz hasonlóan kamrasír volt - mélysége 3,78 m - amelyben egy 49-50 éves férfi nyugodott. A rablás következtében csak a koporsóvasalások maradtak a sírban. A többi sír egyszerú földsír volt, amelyeket a 8. sír kivételével ugyancsak kiraboltak. ${ }^{92} \mathrm{~A}$ megmaradt mellékletek segítenek a temető keltezésében. A 7. sírban egy háromrészes, tausírozott díszú övgarnitúra maradt (4. kép 6). A csat és az ellenveret egyértelmú, a 3. darabot Sági szíjvégnek határozta meg, ${ }^{93}$ de ez inkább egy hátveret lehetett. Ez a garnitúra a 6 . század végére, a 7 . század elejére keltezhetó. ${ }^{94} \mathrm{~A} 8$. sírban 15 pasztagyöngy mellett vascsat volt a medencében, a két térd között pedig nyéltüskés vaskés, pecek nélküli kis négyszögletes ezüst csatkeret, másik ugyancsak kisméretú ezüstcsat, a hozzá tartozó, vonallal összekötött három bemélyített körrel díszített Martinovka-típusú szíjvéggel (4. kép 7). Utóbbiak nem lehettek lábszárszíj (Wadenbindengarnitur) tartozékai, mert csak egy példány van belölük, ${ }^{95}$ helyzetükből és környezetükből adódóan egy tarsoly zárására szolgálhattak. A sírok kivétel nélkül $\mathrm{Ny}-\mathrm{K}$ tájolásúak. ${ }^{96} \mathrm{~A}$ tíz sír között nincs gyermeksír, és az eredeti publikáció szerint ki-

91 SÁGI 1991.

92 Sági K. szerint ez a sír is rablott volt, mert a koponya mellett egy borda volt (SÁGI 1991, 115). A váz egyébként anatómiai rendben helyezkedett el. Koporsós temetkezés lévén valószínú, hogy csak állati bolygatásról van szó.

93 SÁGI 1991, 122.

94 MÜLleR 2016, 282; VIDA 2018, 142-143.

95 VIDA 2018, 170. A lábszárszíjak között nincsenek kora bizánci szíjvégek és csatok.

96 Sági K. az 1. sírt tévesen K-Ny tájolásúnak határozta meg (SÁGI 1991, 113), a 2. sír tájolása a bolygatás miatt nem határozható meg. A többi sír tájolását Sági nem adta meg, de a sírrajzok alapján kivétel nélkül Ny-K tájolásúak. Heinrich- lenc nó mellett egyetlen férfit (4. sír) temettek a temetőbe. Valószínúsítem, hogy az övgarnitúrás 8. sírba is férfit temettek. ${ }^{97} \mathrm{~A}$ több unikális tárgyat tartalmazó temetóbe Sági szerint a langobárd időszakban egy visszatelepedett keleti gót család temetkezett, a legkésóbbi sír 569 tavaszára keltezhető. ${ }^{98}$ Bóna István ${ }^{99}$ majd magam is langobárd korinak $^{100}$ határoztuk meg. Utóbb már egy 568 után betelepedett előkelő germán közösség temetőjének gondoltam, ${ }^{101}$ amely része a Keszthelykultúrának. Legutóbb Heinrich-Tamáska Orsolya és munkatársai vizsgálták meg részletesen a 2. sír aranytárgyait, és jutottak arra az eredményre, hogy ebben a sírban a legfelsó germán elithez tartozó nőt temettek 600 körül, amikor ez a terület már az avar birodalom része volt. ${ }^{102}$

\section{A Keszthely-Fenékpuszta, Pusztaszentegyházi dúlői temetó}

A középkori Fenék falu templomáról elnevezett domb területén Lipp Vilmos ásott először 1883ban. ${ }^{103}$ A domb tetején, a késő román falusi templom alapfalait 1913-ban Csák Árpád, majd 1948ban Radnóti Aladár is kiásták. Itt, a templom szentélye alatt tártuk fel 1998-ban az " $\mathrm{A}^{\prime \prime}$ sírt, amely a Fenéki úti 2 . sírhoz hasonlóan egy kamrasír volt, ezt is kirabolták, és ebben is számos értékes melléklet maradt. ${ }^{104}$ Ebben nem egy előkelő nő, hanem egy előkelő harcos nyugodott. A megmaradt mellékletek: stilizált állatfejekkel és beütögetett félkörökkel díszített aranycsat, alsó felületén görög betús felirattal (4. kép 8), a bőrszíjhoz rögzítésre szolgáló két különböző, pajzs alakú verettel és a hozzá tartozó beütögetett félkörökkel díszített, arany szíjvéggel; egy fapohár aranyozott ezüstből készült, II. germán állatstílussal díszített peremverete (4. kép 9), egy római kori, aranyozott ezüst köves gyürü, az intaglio küllős kerékre támaszkodó griff; ép, egyoldalas csontfésú, két végén madár protoméval, csontlemezekból összeállított tokban (4. kép 10); vasolló; egy kovakő, továbbá egy gránátokkal dí-

Tamáska O., Horváth E. és Bendő Zs. tévesen K-Ny tájolást adtak meg (HEINRICH-TAMÁSKA-HORVÁTH-BENDŐ 2018, 313).

97 Sági K. szerint Éry Kinga csak az első hét sír nemét és életkorát határozta meg, a 8 . sírról Sági vélte, hogy ugyancsak női temetkezés (SÁGI 1991, 113).

98 SÁGI 1989, 301. Sági 1991-ben már csak délről származó germánokról szólt (SÁGI 1991, 132-135).

99 BÓNA et al. 1993, 157-158.

100 MÜLLER 1996b.

101 MÜLLER 2002, 33-35; MÜLlER 2016, 282, 51. jegyzet.

102 HeINRICH-TAMÁSKA-HORVÁTH-BENDŐ, 2018.

103 Lipp 1886, 140. A feltárás leírását még Kuzsinszky is „regényesnek" tartotta (KUZSINSZKY 1920, 46-47).

104 MÜLLER 2000a; MÜLLER 2014, 28-31. 
szített, aranyozott ezüst piramisveret (4. kép 11), ami arra utal, hogy a sírban egy díszes spatha is volt. ${ }^{105} \mathrm{~A}$ domb legmagasabb pontján, az " $\mathrm{A}^{\prime \prime}$ sírban nyugodott a közösség vezetője. Töle É-ra és K-re a lejtón helyezkedtek el a kíséret és a szolgák sírjai. Radnóti 1948-ban 3, mi 1998-2000-ben 109, összesen 112 kora avar kori temetkezést tártunk fel. A középkori objektumok legalább 24-28 sírt semmisítettek meg, így a kb. 45 m hosszú és 29 m széles temető eredetileg 136-140 sírból állhatott. Csak az „, $\mathrm{A}^{\prime \prime}$ sírt rabolták ki. A feltárt sírok $30 \%$-a volt melléklet nélküli. Minden női temetkezés tartalmazott mellékletet. A sírok egy kivétellel Ny-K tájolásúak, a K-Ny tájolású gyermeksírban volt az egyetlen kerámia, és avar módra a tor során elfogyasztott három állat - egy kecske és két juh - nyúzott bőrét a koporsóra terítették. Ez az egyetlen pogány temetkezés, a többiben sem étel sem ital melléklet nem volt, a közösség a többi egykorú fenékpusztai közösséghez hasonlóan keresztény lehetett. Erre utal a kereszt egy galamb fibulán (5. kép 1), ${ }^{106}$ a tausírozott kereszt egy másik fibulán, a keresztek egy préselt övgarnitúrán és egy függő, kereszt alakú csüngővel. A sírokban nem volt kőpakolás, ami az eródben és a D-i fal előtt általános. A leletanyag részben egyezik a D-i erődfal előtti köznépi temetővel: a függők csaknem kétharmada öntött, bronz kosárkás függő (5. kép 2-3), lemezes kosárkából csak egyetlen példányt ismerünk (5. kép 4). A 14 ruhatú vasból készült (5. kép 5). Egy bronz- vagy ezüsttú négyszögletes taggal és üvegberakással a BONOSA tú egyszerúsített változata. Volt még egy-egy öntött gömbcsüngős és gúlacsüngős bronzfüggő is. Egy csillag alakú csüngőjü függő (5. kép 6) a Balkánról származhatott. Korongfibulák nincsenek. A 11 fibula többsége római kori darab. Egy-egy ezüst galamb- és lófibula (5. kép 7) mellett előkerült három vasból készült aláhajtott lábú, széles kengyelú fibula (5. kép 8), amelyek a Balkánról kerülhettek csak ide. 35 temetkezés tartalmazott gyöngyöket. ${ }^{107} \mathrm{Az}$ " "A" síron kívül még 7 sírban volt csontfésú, valamennyi kétoldalas. A kelet mediterrán Yassi Ada-típusú csat (5. kép 9) mellett előkerültek kifejezetten germán csatok is. A 14 övgarnitúra fele hiányos. A Martinovka-típus mellett vannak kereszttel, dudorokkal és szalagfonattal díszített préselt darabok. Egy bronzlemezból kivágott veretet beütögetett félkörökkel díszítettek. Az " $\mathrm{A}$ " síron kívül két sírban volt sax, egyben tôr, egyben pedig 10 köpús nyílhegy és egy balta. A leletek

\footnotetext{
105 A leletek vizsgálatának eredményei: BENDŐ-HEINRICH-TAMÁSKA-HORVÁTH 2014.

106 STRAUB 2002.

107 PÁSZTOR 2014.
}

alapján a temetôt 568 után nyitották meg, és egy vegyes, több helyről származó, talán nem is egy időben ideérkezett népesség temette ide a halottait. Az avarok etnikailag nem voltak jelen, egy bogozó kivételével egyetlen jellegzetes korai avar tárgy sem került eló. A legtöbb lelet a keletalpi, dalmáciai késő antik anyaggal mutat rokonságot. Vannak olyan, a Balkánról származó tárgyak, amelyek egy része a Kárpát-medencében eddig csak innen ismert, és olyan, amelyről feltételezhető, hogy nem importként kerülhetett ide. ${ }^{108}$ Ezenkívül vannak germán tárgyak - fegyverek, csatok, fésúk -, amelyek germán népesség jelenlétére utalnak. A közösség vezetője maga is egy germán harcos volt. A temetó legkésőbbi sírjainak mellékletei egy akkulturációs folyamatra utalnak. A temetô használata 630 táján szúnt meg.

\section{A Szigligeti lelet}

Az 1890-es évek közepén a Várhegy Balatonra néző oldalán, Frisch László birtokán, szólő alá forgatáskor több sírt megbolygattak. Darnay Kálmán csak két sír anyagát tudta megszerezni. Az 1. sírból egy áttört, filigrán drótból összeállított kosárkájú függőt (6. kép 1), amelynek elólapja zárt, filigránnal, továbbá foglalatban egy nagyobb és négy kisebb üvegbetéttel díszített. A karikája elôl kiszélesedik, és rajta kis foglalatban üvegbetét található. Egy bronztút, amelynek végén filigrándrótból összeállított gömb van (6. kép 2), tetején egy, felső felén körbe négy foglalatban üvegbetéttel. A tú szárát is filigrándróttal tekerték körbe. Továbbá három gyöngyöt, feltehetóen szemesgyöngyöket, a 2. sírból egy ovális fejú bronzgyúrüt és egy préselt, geometrikus díszú, ezüst nagyszíjvég előlapját (6. kép 3). ${ }^{109}$ A függő átméróje - 3,6 cm - megfelel a korai avar kori kosaras függők méretének, ${ }^{110}$ de az elöl kiszélesedő karika a későbbi példányokra jellemző. ${ }^{111}$ A gömbbel díszített tú a horreumi 6. sír tújével rokon. ${ }^{112}$ A préselt szíjvég pontos párhuzamát nem ismerjük, de bizonyosan kora avar kori darab.

108 VIDA 2018, 132-133 joggal feltételezi, hogy az egyszerú Yassi Ada-típusú csatok nem lehettek sem kereskedelmi áruk, sem hadizsákmány részei, így feltételezi, hogy viselőikkel kerültek a Kárpát-medencébe.

109 DARNAY 1901, 180, 6-7. kép. Részletesebb Hampel leírása és rajza: HAMPEL 1905, II, 699-700.

110 A D-i erődkapu előtti temetőben a 2000/151 sír nagyobbik függőjének ugyanekkora a karikája, és az áttört kosárka is filigrándrótból készült: MÜLLER 2010, Taf. 100, 9.

111 A karika elejének díszítése már a horreumi 8. sír karikáján feltünt (BARKÓCZI 1968, Pl. LIX, 1-2).

112 BARKÓCZI 1968, Pl. LVII, 3. 


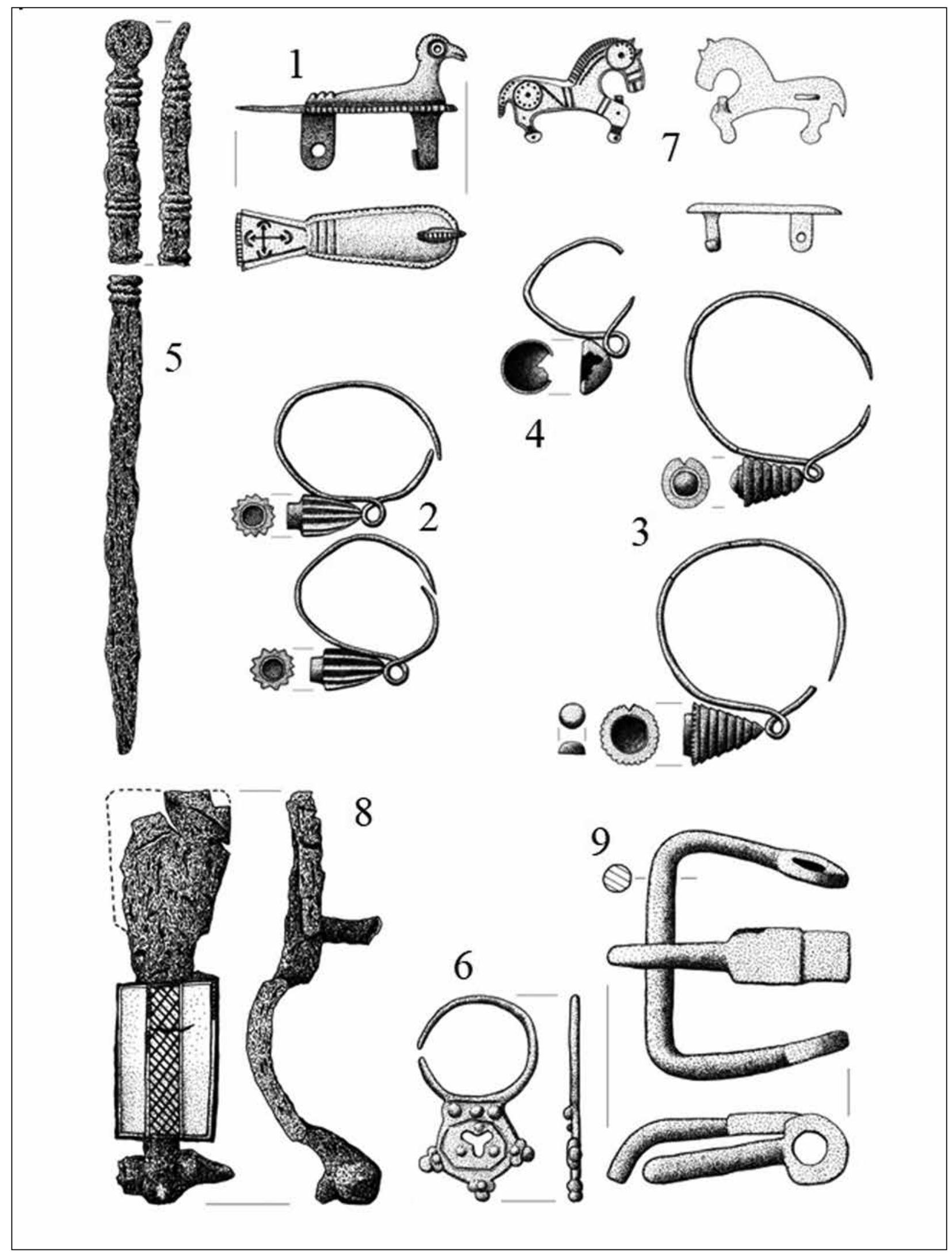

5. kép. 1-9: Keszthely-Fenékpuszta, Pusztaszentegyházi dúlői temető. Különböző léptékek Fig. 5. 1-9: Keszthely-Fenékpuszta, Pusztaszentegyházi-dúlő cemetery, Various scales 


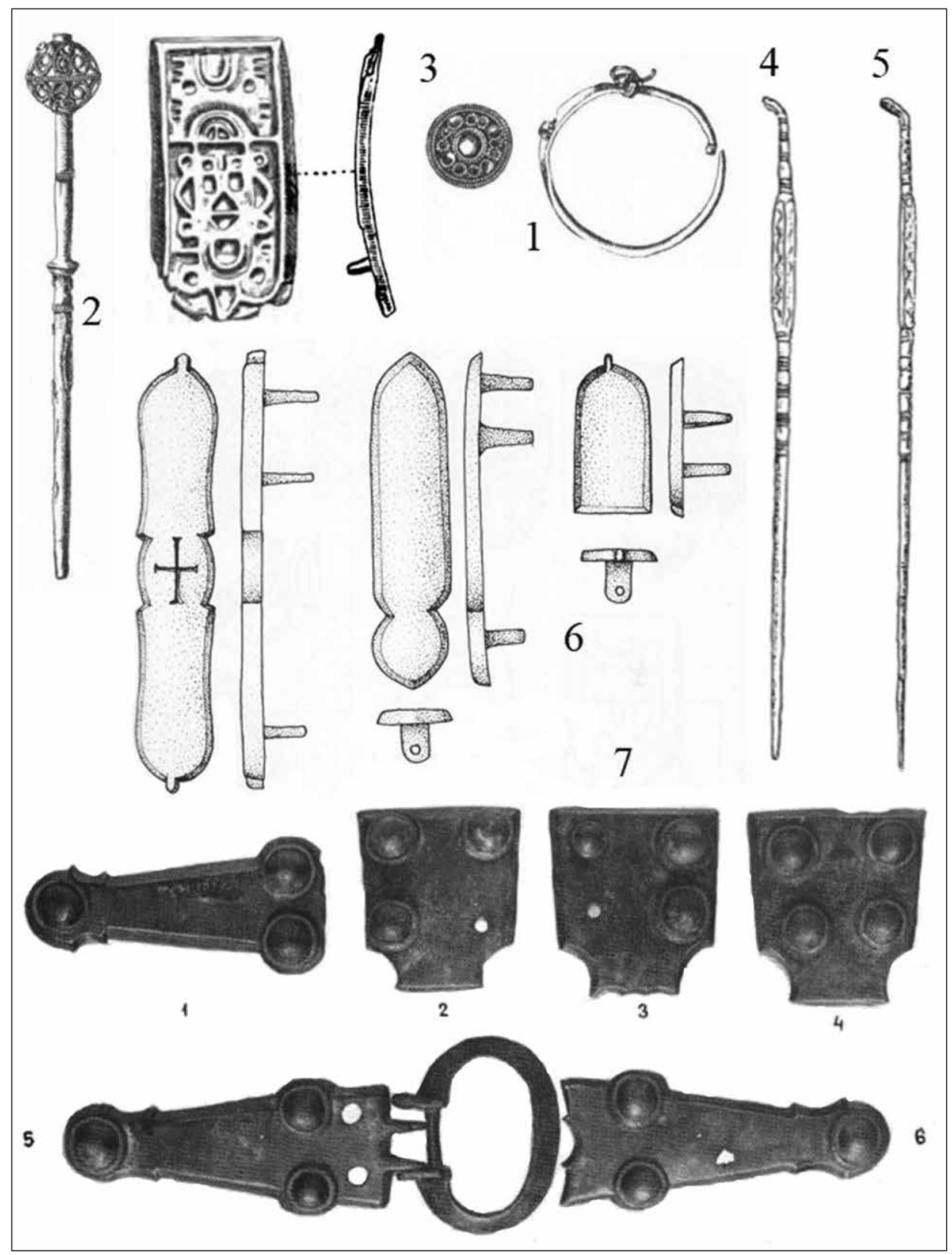

6. kép. 1-3: szigligeti lelet; 4-7: Keszthely-dobogói temető. Különböző léptékek

Fig. 6. 1-3: Szigliget assemblage; 4-7: Keszthely-Dobogó cemetery. Various scales 
A két sír a 7. század első felére keltezhető. A Fenékpusztán kívül előkerült Keszthely-kultúrás temetők nagy kiterjedésúek, az avar kor végéig használatban voltak, többnyire több ezer sírból állnak. Ha itt is ilyen temető lett volna, azóta újabb síroknak kellett volna előkerülniük. Ezért feltételezem, hogy itt egy kis sírszámú, családi temetőról van szó, amelyet a fenékpusztaiakhoz hasonlóan csak a kora avar korban használtak.

\section{A Keszthely-dobogói temetó}

Az egyik legnagyobb avar kori temetőnk, Keszthelytől E-ra, a murvabányászatra használt Alsó Dobogó domb D-i lejtőjén került elő. Még mielőtt Lipp megkezdte volna a feltárást, mintegy ezer sírt semmisítettek meg a kőbányászás során. Lipp 1879. június és 1882. szeptember 18. között 2434 sírt tárt fel. ${ }^{113}$ Sajnos csak az 1882. május 11. és szeptember 18. közötti naplója került elő, amiból kiviláglik, hogy milyen tempóval dolgozott. ${ }^{114}$ Publikációjában együtt dolgozta fel a dobogói és a Keszthely városi vagy sörházkerti temető anyagát, ${ }^{115}$ nem mindig elkülönítve, hogy melyik tárgy melyik temetőból származott. Kiss Gábor elévülhetetlen érdeme, hogy felkutatta a dobogói ásatás dokumentumait, és ismertette a MNM-ba került anyagot. ${ }^{116}$ A temető nem lett teljesen feltárva. Csák Árpád 1898-as ásatásán 64 sír került elő, eredményeiről Kuzsinszky közölt öszszegzést. ${ }^{117}$ Kőbányászás során még az 1960-as évekig bolygattak meg sírokat, és 1948-ban Párducz Mihály is feltárt néhány melléklet nélküli temetkezést. ${ }^{118}$ A sírok tájolása döntően Ny-K, csak a domb alján, a legkésőbbi sírok között akadtak K-Ny tájolásúak is. Lipp nem említi, hogy a vázak rossz fenntartásúak lettek volna, a kőpakolás csak elvétve fordult elő. ${ }^{119}$ Csak a sírok egy részénél figyelt meg koporsónyomokat, több koporsót vasszegekkel állítottak össze, ami a többi temetőben nem fordult elő. A síronként ismertetett temetőrészben a temetkezések 52\%-a

113 KISS 1997, 115. A régészeti topográfia adata 2088 sírról (BAKAY-KALICZ-SÁGI 1966, 77, 21/7. lh.) Lipp téves összesítésén alapul (LIPP 1884, 8).

11494 ásatási nap alatt három ásatási munkással 756 sírt tárt fel, tehát naponta nyolcat. A napló síronként sorolja fel a leleteket (KIss 1997, 120-133).

115 LIPP 1884.

116 KIss 1997. A leletek zöme a Magyar Nemzeti Múzeumba került, de jutott belőle Csornára, Győrbe, Sümegre és Szombathelyre is (BAKAY-KALICZ-SÁGI 1966, 77).

117 KUZSINSZKY 1920, 105-107.

118 BAKAY-KALICZ-SÁGI 1966, 77.

119 LIPP 1884, 11. „....néhány sír alsó körülete ökölnyi nagyságú kövekkel volt kirakva...néhányban a sírfenék négy szegletébe ködúcok voltak ékelve." volt melléklet nélküli. Főleg a férfi és a gyermek sírok. A női sírokban a Keszthely-kultúrára jellemzó tárgyak korai típusai is megtalálhatók: volt egy arany kosaras függópár és sok ezüst (7. kép 1), illetve bronz példány. A közölt darabok mind nyitott kosarasok, elöl díszes, kerek lappal lezártak. Öntött példányokat nem említ. A többi korai temetőből is ismert öntött, gömbcsüngős függők itt is voltak, de előfordultak két félgömbből összeállított, ezüstlemezből préselt gömbök is. ${ }^{120}$ A ruhatúk közül korai típust képviselnek a vastúk és az ezüsttúk, amelyek szára négyszög alakban megvastagított (6. kép 4-5). Korongfibulából 16 darab került elő. Ókeresztény jelentéssel bír a „császár apotheosis” (7. kép 2) és a „hódolat a kereszt előtt", a többi préselt előlappal és üvegberakással vagy annak imitációjával díszített. ${ }^{121}$ A leletegyüttes része még egy érdekes korongfibula, amelyet tévesen alsópáhokiként (hévíziként) is közöltek. ${ }^{122}$ A peremén lévő stilizált madárfejek alapján a germán filigrános korongfibulák leegyszerúsített helyi utánzata (7. kép 3), amely a 6-7. század fordulóján készülhetett. ${ }^{123}$ Viszonylag gyakori a nói sírokban az orsógomb vagy az orsókarika. A férfiak legértékesebb viseleti tárgyai a veretes övek voltak. A napló szerint a veretes övvel eltemetett férfiak aránya nem érte el a $10 \%$-ot. A legkorábbiak közé tartozik egy kárpát-medencei unikum, egy bronzból öntött ún. „hagymafejes” garnitúra (6. kép 6), egy bizánci készítmény, amely a 6 . század utolsó harmadára keltezhető. ${ }^{124}$ A korai avar korban készültek az ezüst- vagy bronzlemezből préselt veretek. Csak a temetó egy bizonyos részén kerültek eló a kelet-alpi (itáliai) típusú öntött övgarnitúrák (6. kép 7). ${ }^{125}$ Ugyancsak korai a Pápa-Úrdombtípusú tarsolyzáró csat és szíjvég (7. kép 4). ${ }^{126}$ A publikáció csak a városi temetőból említ lovas

${ }^{120}$ Lipp 1884, 33, 269. rajz; KIss 1997, 4. t. 9.

${ }^{121}$ Lipp csak 11 darabot közölt (Lipp 1884, 333-343. kép), Kiss tizenöt darabot (Kiss 1997, 5. t. 5-19), Garam csak 5 példányt közölt, hármat keszthelyiként (GARAM 1993).

122 Hampel a Balatoni Múzeumban őrzött páhoki leletként közölte: HAMPEL 1905, I, 505-506, Fig. 1515; II, 705-706. Így dolgozta fel Vida is (VIDA 2005, 437, Abb. 2, 3). Fotóját Csák dobogói ásatásából származó darabként Kuzsinszky közölte (KUZSINSZKY 1920, 106, 146. kép). Ugyanarról a tárgyról van szó, mert Hampel és Kuzsinszky leírása is említi, hogy a peremen lévő hat kerek üvegbetétből csak kettő maradt meg.

123 VIDA 2005, 437.

124 BÓNA 1961-62, 57-59, Taf. XXII, 9-20. A kereszttel díszített szijvéget Bóna csatolta a garnitúrához. GARAM 2001, 130, Taf. 96 , 1. Csak a függesztőverethez hasonló darab került eló Mezőberényben (GARAM 2001, 130, Taf. 96, 2).

125 BÓNA 1961-62, Taf. XX-XXI; KIss 1997, 135, 1. t. 1-31.

126 Kiss 1997, 2. t. 15-16; GARAM 2001, 111, Taf. 76, 3. (Lipp nem nevezte meg, hogy melyik temetőben találta, de a leltári szám alapján egyértelmú, hogy a dobogói temetóből származik.) 
sírokat. ${ }^{127}$ A fegyverek közül a balták és fokosok a leggyakoribbak. A napló által leírt sírok közül öt, tehát a férfisírok 3\%-a tartalmazott fokost. ${ }^{128}$ A nyílhegyek között egyaránt előfordultak háromtollú, avar és köpús, germán nyílhegyek. De nem tudjuk, hogy ezek a fegyverek mekkora hányada került elő a temetó késői sírjaiból. A lándzsaként közölt darab - a szúk köpú alapján valószínúleg csak egy nagyobb, köpús nyílhegy volt. ${ }^{129}$ Reflexíj-merevító csontlemezek csak a városi temetőben voltak. Bár a sírokból több vasvagy bronzpántos favödör és néhány kerámia is előkerült - az első 1594 sírból hat, valamennyi gyermeksírból ${ }^{130}$ - hús mellékletre utaló állati csontokat nem talált, ${ }^{131}$ és nem lehet kétséges, hogy a temetőt egy keresztény közösség használta. A leletek alapján a temetőt 568 után nyitották meg. Korábbi elózménynek nincs nyoma. ${ }^{132}$ Ezért egyetértek Kiss Gáborral, hogy az ide temetkezők 568 után vándoroltak be. Az eddig ismertetett temetőkkel ellentétben ezt 630 után is használták. Hiányoznak ugyan a legkésőbbi övgarnitúrák, a kettős lapú szijvégek és a keskeny pajzs alakú veretek, akárcsak a legnagyobb átmérójú kosaras függők, de az egyszerú drótékszerek alapján a temető feltehetóen az avar kor végéig használatban maradt. ${ }^{133}$

\section{Gyenesdiás, döngelegi temetó}

A község K-i szélén, az uradalmi szőlő területén, a „Tavernától” DNy-ra, a lejtőn, egy kis domborulaton, ún. döngelegen az első sírok már az 1880-as években elókerültek. ${ }^{134}$ A filoxéravészt követő szőlőtelepítés során a nagy kiterjedésú temető jelentős részét megsemmisítették. Az erózió miatt a sírok többsége sekély mélységú lehetett, a legmélyebb temetkezések feltehetóen még érintetlenek. Az 1941-es rigolírozási munkálatok

127 LIPP 1884, 17, 22-23. kép. Kiss szerint Dobogón a feltárás előtt került elő egy vagy néhány lovas sír, és közöl két zablát (KISS 1997, 134, 7. t. 10-11), de ezek máshonnan származhattak. Ha lettek volna a Dobogón is lovas sírok, a több mint 2000 temetkezés feltárása során is eló kellett volna kerülniük. Ha valóban találtak lovas sírokat, azok elókerülési helyük alapján a legfiatalabb temetőrészhez tartoztak.

128 KIss 1997, 138.

129 Lipp 1884, 30. kép; Kiss 1997, 7. t. 7.

130 Kiss 1997, 134.

131 Nehéz értelmezni, hogy „egyes félig vagy egészlen elszenesedett állat-, kivált madárcsontok csaknem minden sírban a csontváz körül, majd a töltelékföldben találtattak" (LIPP 1884, 14).

${ }^{132}$ A Hévízre vezető út túloldalán feltárt késő római temetőt csak 374-ig használták (SÁGI 1981), tehát egy csaknem két évszázados hiátus van a két temető között.

133 KISS 1997, 141; BAKAY-KaLICZ-SÁGI 1966.

134 LIPP 1884, 9. során Dornyay Béla szerint hozzávetőleg újabb 300 sírt bolygattak meg. ${ }^{135}$ Az előkerült leletekből több gyưjteménybe jutott, Csák Árpád több száz, sírösszefüggés nélküli tárgyat szerzett meg a Balatoni Múzeum részére. Ebből Hampel és $\mathrm{Ku}$ zsinszky is közölt egy-egy válogatást. ${ }^{136} \mathrm{~A}$ megmaradt tárgyak között van egy préselt, pajzs alakú bronzveret (7. kép 5) az ezüstözés nyomaival, szélén apró dudorokkal, belül két poncolt 8-as mintával díszítve. ${ }^{137}$ Egy a verettel egybeöntött bronzcsat, a karika ovális, a háromszög alakú veret profilált, a három rögzító szegecsnél köríves. Felületét beütögetett félkörök díszítik (7. kép 6). ${ }^{138}$ A Meroving ízlésú csat legjobb analógiáit a környékről ismerjük. ${ }^{139}$ Ugyancsak a korai tárgyak közé sorolható egy madár alakban végződő bronztû́ (7. kép 7). ${ }^{140}$ Egy kis méretü, nyitott kosaras, elöl kúpos ezüstfüggő (7. kép 8) lehet, hogy már a 7. század közepén volt használatban.141 A döngelegi temetőtól D-re a 71-es főút mentén egy késő császárkori temető terül el, de ennek a használata a 4 . század végéig tartott. ${ }^{142}$ A gyenesdiási temetőt 568 után egy bevándorolt közösség nyithatta meg, és a leletek (pl. fonatdíszes pajzs alakú övveret, öntött csillagcsüngős bronzfüggó, griffes-indás nagyszíjvégek, liliomos díszú nagyszíjvég, hosszú, hasított szárú stílustú, nagy méretú kosaras függők) alapján az avar kor végéig folyamatosan használták.

\section{Kéthely-Melegoldal-i temetó}

1988-ban földkitermelés során megbolygattak egy Keszthely-kultúrába sorolható temetőt. Költő László 1988. júliusban és novemberben, illetve 1989. júniusban összesen 48 sírt tárt fel, két csoportban, egymástól mintegy $30 \mathrm{~m}$-re. A két terület közötti sávban lévő sírokat 1990-ben megsemmisítették. A temetőről összefoglaló értékelés,

\footnotetext{
135 DORNYAY 1941, 32-35.

136 HAMPEL 1905, II, 700-702, III, Taf. 443; KUZSINSZKY 1920, 107 109.

137 KuZSINSZKY 1920, 146. ábra 6; MÜLler 2007, 3. kép 8.

138 KUZSINSZKY 1920, 146. ábra 10; MÜLLER 2007, 3. kép 7.

139 Balatongyörökön a Kövesmezőn felszíni leletként került elő (MÜLLER 2000b, 33-34) egy szinte pontos mása a mi darabunknak. Ugyanilyen formájú csak lényegesen kisebb csat került elő a D-i erődfal előtti temető 1976/20. sírjában (STRAUB 2002, 212, 8. kép 20/2). Egyszerúbb változatai, amelyek verete nem ilyen profilált, de ugyanígy félkörökkel díszített, a D-i erődkapu előtti 1999/21. sír és a Pusztaszentegyházi dúlőben az 1999/72. sír csatja (MÜLLER 2010, Taf. 84, 1; MÜLlER 2014, Taf. 14, 3).

140 HAMpel 1905, III, Taf. 443, 7.

141 KUZSINSZKY 1920, 148. ábra 1.

142 MÜller 2007, 25-27.
} 


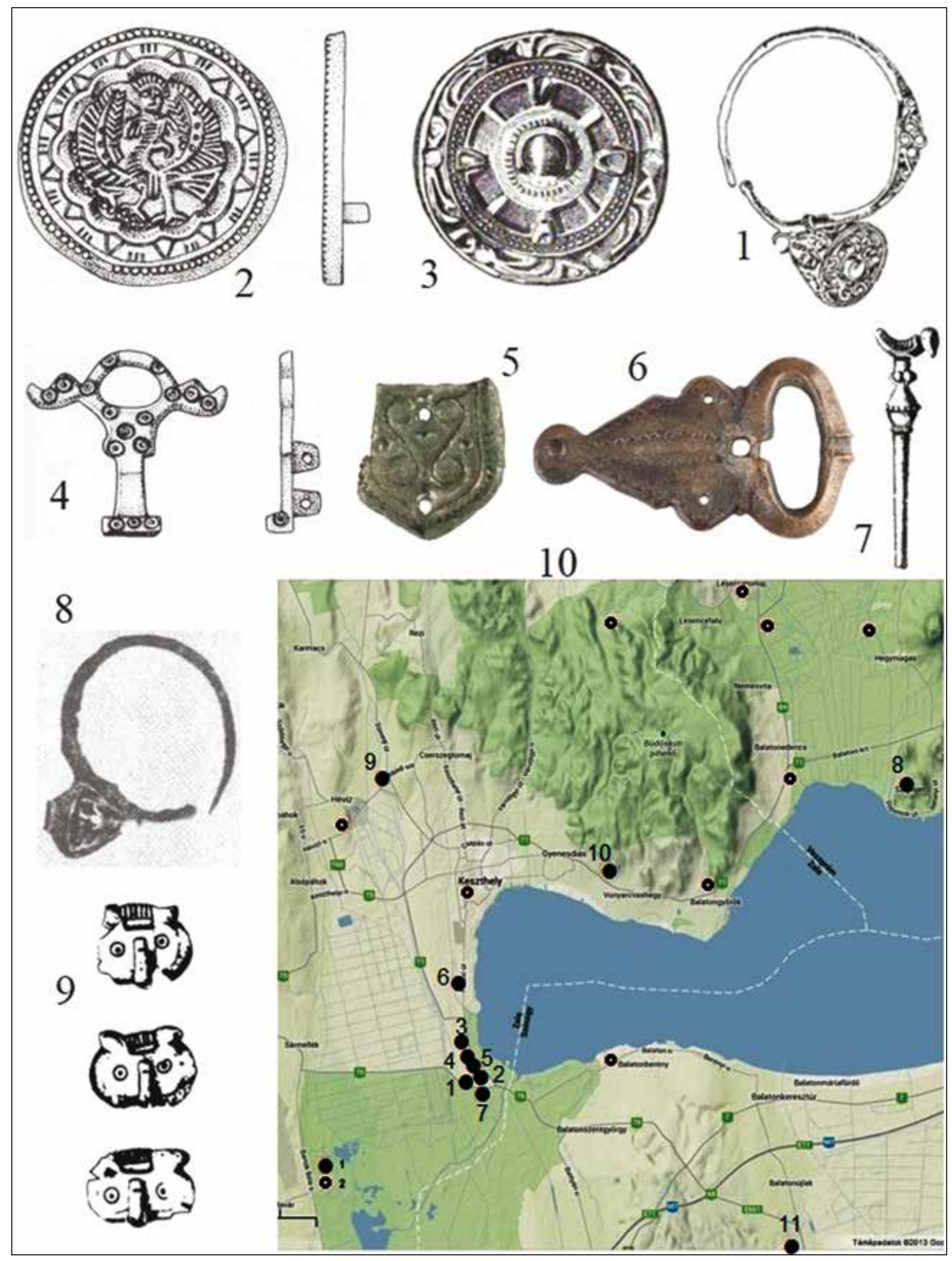


7. kép. 1-4: Keszthely-Dobogó; 5-8: Gyenesdiás, döngelegi temető; 9: Kéthely-Melegoldal-i temető. Különböző léptékek; 10: a Keszthely kultúra temetői. (1: zárt kör: korai szakasz; 2: nyitott kör: késői szakasz. 1: Keszthely-Fenékpuszta, Lipp-féle temető; 2: Keszthely-Fenékpuszta, Csák-féle temető; 3: Keszthely-Fenékpuszta, ókeresztény bazilika; 4: KeszthelyFenékpuszta, horreumi temető; 5: Keszthely-Fenékpuszta, déli erődfal előtti temető; 6: Keszthely-Fenéki úti temető; 7: Keszthely-Fenékpuszta, Pusztaszentegyházi dúlói temető; 8: Szigliget; 9: Keszthely-dobogói temető; 10: Gyenesdiás, döngelegi temető; 11: Kéthely-Melegoldal-i temető)

Fig. 7. 1-4: Keszthely-Dobogó; 5-8: Gyenesdiás, Döngeleg cemetery; 9: Kéthely-Melegoldal cemetery. Various scales; 10: cemeteries of the Keszthely culture. (1: zárt kör: early phase; 2: nyitott kör: late phase. 1: Keszthely-Fenékpuszta, cemetery excavated by Vilmos Lipp; 2: Keszthely-Fenékpuszta, cemetery excavated by Árpád Csák; 3: Keszthely-Fenékpuszta, early Christian basilica; 4: Keszthely-Fenékpuszta, horreum cemetery; 5: Keszthely-Fenékpuszta, cemetery by the southern fort wall; 6: Keszthely-Fenéki Road cemetery; 7: Keszthely-Fenékpuszta, Pusztaszentegyházi-dúlő cemetery; 8: Szigliget; 9: Keszthely-Dobogó cemetery; 10: Gyenesdiás, Döngeleg cemetery; 11: Kéthely-Melegoldal cemetery)

és az első 27 sír rövid leírása jelent meg. ${ }^{143} \mathrm{Ez}$ alapján a temetkezések döntő többsége a Keszthely-kultúra késői idószakára - 7. század második felére, a 9. század elejére - keltezhető. A sírok Ny/DNy-K/ÉK tájolásúak, a gödrök alján nem volt kőpakolás. A feltárt terület É-i szélén azonban két korai temetkezés került elö. A 3. sírban egy soktagú övgarnitúra volt, ezüstből préselt álcsatos veretekkel (7. kép 9). Ez a típus a 6. század második és a 7. század első felére keltezhető. ${ }^{144} \mathrm{~A}$ 13. sírban ezüstlemezból préselt, gömbcsüngős függőpár volt, amit a 7. század első negyedére-felére keltezhetünk. ${ }^{145}$ Ennek a keltezésnek nem mondanak ellent a sírban talált szemesgyöngyök. ${ }^{146} \mathrm{Az}$ átmenetet a 24. sír jelenti, ${ }^{147}$ amelyben kis méretú, ezüst kosaras függőpár ${ }^{148}$ és rövid, hasított szárú ezüst stílustú is volt. A kis sírszám ellenére feltételezhető, hogy előzmények hiányában 568 után egy bevándorolt keresztény ${ }^{149}$ közösség nyitotta meg a temetőt, és folyamatosan használta legalább a 8. századig.

A korai Keszthely-kultúra leleteit tehát eddig 11 temetőből ismerjük (7. kép 10). ${ }^{150}$ Ebből 7 a fe-

143 KÖLTŐ 1991.

144 Samu-DAim 2018, 222-224, Abb. 13. A IV. típus 5a-ba tartozik.

145 KIss A. 1996, 193. Vida szerint a kora avar kor leggyakoribb függő típusa a késő antik előzményekre visszavezethetó öntött gömbcsüngős függők nyomán készültek (VIDA 2018, $46-47)$.

${ }^{146}$ A két korai sír közül csak az egyikbe temettek nőt. Így előfordulhatott, hogy éppen ez a női sír nem tartalmazott sem kosaras függőt, sem stílustút. Ettől függetlenül az egész temetőt a Keszthely-kultúra lelőhelyének kell tekinteni.

147 KöLTó 1991, 174, 7. tábla.

148 S. PERÉmi 2000, 42 és I. táblázat I/b típus. Áttört kosár, az eleje kúpos, a 7. század közepén megnyitott temető korai szakaszára jellemző.

${ }^{149}$ Kerámia melléklet egyetlen gyermeksírban volt, állati csont nem került elő (KöLTó 1991, 171)

150 A páhoki (hévízi) temetőt is ide szokás sorolni, de a Magyar Nemzeti Múzeumban páhokiként beleltározott kora avar kori leletek kivétel nélkül a fenékpusztai ásatás során kerültek elő (MÜLLER 2012). A többi Keszthely-kultúrás temetőből csak a késői fázis leleteit ismerjük, de ezek területén nem folyt szakszerú feltárás, ezért elképzelhető, hogy némelyiknek van egy kisebb sírszámú, a korai fázisba tartozó része is. nékpusztai erőd területén vagy környékén helyezkedik el, és a 6. század utolsó - a 7. század első harmadára-felére keltezhető. Ezzel egyidős a szigligeti lelet is. Legalább három távolabbi temetó használata nem szakadt meg 630 után, hanem minden valószínúség szerint az avar kor végéig temetkeztek beléjük. Ez önmagában is indokolja a korai Keszthely-kultúra fogalmának használatát, mert ezeknek a lelőhelyeknek a használata csaknem két és fél évszázadon át folyamatos, így nehéz lenne a temetőknek csak egy részét a Keszthely-kultúrához tartozónak tartani.

Mint említettem, a korai fázis meghatározásához nem elég csak a korábban idetartozónak vélt tárgyakat, a kosaras függóket, a stílustúket és a korongfibulákat, ${ }^{151}$ hanem ennek a 11 lelöhelynek a teljes anyagát kell figyelembe venni. Bálint Csanád is joggal állapította meg, hogy a Kovrig által használt elnevezés, ",a kosárkás függők népe" mára idejétmúlt. ${ }^{152} \mathrm{~A}$ teljes anyag figyelembevételével derül ki, hogy a kosaras függók, a stílustúk és a korongfibulák használatán túl, sem a rítus, sem a tárgyi anyag tekintetében nem teljesen egységesek ezek a temetők. Ez pedig önmagában cáfolja, hogy ezekbe a temetőkbe kizárólag a tovább élő, késő antik népesség temetkezett volna, hiszen akkor sokkal egységesebbnek kellene lennie az anyagi kultúrának. Ez a számbavétel tudja igazolni, hogy a Keszthely környéki temetők leleteinek összetétele lényegesen eltér a többi dunántúli korai avar „,körzet” ${ }^{153}$ anyagától. A következőkben hasonlítsuk össze a 11 lelőhely válogatott temetkezési rítusait, tárgyait és díszítési motívumait. Kihagytuk az összehasonlításból azoknak a tárgyaknak egy részét, amelyek csak egyetlen lelőhelyról ismertek: a horreumi temetőből a hajhálót díszítő aranycsövecskéket, az

\footnotetext{
151 Szokás még ide sorolni a kígyófejes karpereceket, de ezek egyetlen hiteles korai sírból nem ismertek. A Lipp által fenékiként közölt darabok pedig a páhoki (hévízi) temetőből származnak (MÜLLER 2012).

152 BÁLINT 2019, 55.

153 Legutóbbi felosztás: BÁLINT 2019, 48-64.
} 
aranybullát, a bizánci félhold alakú csüngős függőt és a gallérdíszt, a sas- és S-fibulákat; a D-i erődfal elótti temetóből a fonott, kereszt alakú fibulát, a fátyoltúket, a balta alakú fejben végződő túket, a korábbi kengyelfibulát; a Fenéki úti temetőből a cloisonné csüngőkat, az aranygyöngyöket, az éremlenyomatokat, a kettós, díszfüggő vereteket, a brokát aranyszálait, a pajzs alakú csatrögzítő veretet és a koporsóvasalásokat; a Pusztaszentegyházi dúlői temetőből: az " $\mathrm{A}^{\prime \prime}$ sír övgarnitúráját, piramisveretét és pohár peremveretét, illetve a nagy, kerek veretú, germán vascsatot; a dobogói temetőből a koporsószegeket és a háromtollú nyílhegyeket. ${ }^{154}$

Áttekintve az összehasonlító táblázatot szembetúnő, hogy mennyire nem egységes a 11 temető anyagi kultúrája. Ez még akkor is érvényes, ha tudjuk, hogy a tizenegyból csak hat temetó lett szakszerúen feltárva és ebből kettő sírjainak többségét kirabolták, egyikből pedig mindössze két sír keltezhetó a korai Keszthely-kultúra idószakára. A kőpakolás csak három temetőre jellemző, a Dobogón csak néhányszor fordult elő. Kamrasírba csak a leggazdagabb germánokat temették. A legjellemzőbb női viseleti tárgyak, a kosaras függő, a ruhatú és a korongfibula feltehetóen akkor sem került volna elő a Fenéki úti temetőből, ha nem rabolják ki, hisz ide egy germán közösség temette a halottait. Kosaras függő és ruhatú feltehetően volt a bazilika sírjaiban, mint ahogy a kéthelyi temetőben is, ${ }^{155}$ de a korongos fibula nemcsak a szigligeti, a diási és a kéthelyi anyagból, de a Pusztaszentegyházi dúlői temetóből is hiányzik. Allach-típusú aranyfüggő csak a horreumnál került elő, a többi arany és ezüst kosaras függő áttört kosarú. A zártkosaras, lemezes függők egy kivétellel a D-i erdőfal előtti temetőből származnak, méghozzá döntően az 568 elé keltezhető késő antik temetórészben, a pusztaszentegyházai egyetlen példány (2000/159 sír) pedig feltehetően egy régi, már páratlan darabként, egy zártkosaras, öntött függő párjaként került a földbe. ${ }^{156}$ Egy vagy két részból álló, öntött kosaras függó a Lipp-féle temetőben is volt, de ez a típus alkotja a D-i erődfal előtti és a Pusztaszentegyházi dúlői temető kosárkás függőinek döntő többségét. A keresztbe bordázott darabok csak innen ismertek, ezeket biztosan a helyi bronzmúvesek készítették. ${ }^{157} \mathrm{Az}$ öntött gömb-

\footnotetext{
${ }^{154}$ A korai Keszthely-kultúra temetőiből nem ismertek az avar fegyverek, valószínúsíthető, hogy a háromtollú nyílhegyek a temetó fiatalabb szakaszából származnak.

155 A temető késő Keszthely-kultúrás részében több hasított szárú tú került elő.

156 MÜLler 2014, Taf. 29, 1-2.

157 MÜLLER 2010, 193; VIDA 2012, 73.
}

csüngős függókből Dobogón és a Pusztaszentegyházi dúlőből csak egy-egy példányt ismerünk, a D-i erődfal előtti temetóből ötöt. Feltehetó, hogy ezeket is helyben gyártották. ${ }^{158}$ A ruhatúk közül a vastúk és az astragalos díszítés használata általánosnak mondható, de az egyszerü, négyzetesen megvastagodó szárú túk csak a horreumi, a D-i erődfal előtti és a dobogói temetóből, az ugyanilyen, de a kelet-mediterrán területről származó, kőberakással díszített változat csak a horreumi és a pusztaszentegyházi, míg az ugyancsak kelet-mediterrán eredetú madárfejú túk csak a D-i erődfal előtti és a diási temetőből kerültek elő. ${ }^{159}$ Meglepő, hogy korongfibula sem a diási, sem a pusztaszentegyházi anyagban nem található, mint ahogy a D-i erődfal elótt is csak egy öntött, poncolt díszú és áttört szvasztika mintás korongfibula volt. Meg kell említeni a Lipp-féle és a dobogói temető egy-egy különleges germán korongfibuláját is. Az antik eredetú állatfibulák megtalálhatók a Csák-féle, a horreumi és a Pusztaszentegyházi dúlői temetőben, de nem ismerjük őket sem a dobogói sem a D-i erődfal előtti temetőből. A D-i erődfal előtti temető bronz, aláhajtott lábú fibulájának párhuzamait a Kárpát-medencéből is ismerjük, ${ }^{160}$ de a Pusztaszentegyházi dúlői három széles kengyelú és lábú, ezüstlemezzel díszített, a Dél-Balkánról származó vasfibula az avar birodalom területéről eddig csak innen ismert. Vaskarperecet ugyan csak öt lelőhelyről ismerünk, de használata általánosnak mondható, hiszen még a gazdag horreumi temetőben is előkerült. A férfisírok legjellemzóbb viseleti tárgya a veretes öv volt. Több típusból is csak egy-egy példány került elő eddig: egyedülálló a Kárpát-medencében a hagymafejes garnitúra, amely bizánci készítmény, csak a Lippféle temetóből került elő a Keszthely-Fenékpuszta-típusú szíjvég, ${ }^{161}$ és csak egy-egy lelőhelyről ismert a Főnlak-típusú garnitúra, a rekeszdíszes, vas övveret, a tausírozott garnitúra, a Pápa-Úrdomb-típusú tarsolyzáró és a Yassi Adatípusú csat. Martinovka-díszítés több garnitúrán is felismerhetô, álcsatos és itáliai (kelet-alpi) garnitúrák két-két temetóben is voltak, a hiányos vagy nehezen meghatározható garnitúrákat a soktagú, préselt övgarnitúrák közé soroltuk. Csontfésúket hat lelőhelyről ismerünk. A hoszszabb, egyoldalas fésúk az előkelő germán sírok-

\footnotetext{
158 VIDA 2018, 46.

159 A Csák-féle temető madárfejű túje más jellegú, germán gyártmány.

160 VIDA 2009, 251-253, Fig. 9

161 Párhuzamai a Dunakanyarban és Tolna megyében kerültek elő (NAGY M. 2002, 163, elterjedési térkép; BÁLINT 2019, Fig. $22,4)$.
} 
ban voltak, a késő római korban is kedvelt, kétoldalas darabok a köznépi sírokat tartalmazó temetőkben kerültek elő. A két vasolló egyoldalas fésú mellett volt. A fegyverek germán típusok, és viszonylag ritkák. Avar fegyverek, mint az egyélú kard, a reflexíj vagy a páncéltörő kopja nem kerültek elö. Spatha csak két sírban volt, ${ }^{162}$ sax csak egy temetőből ismert, ${ }^{163}$ köpús nyílhegy három helyen is előkerült, a dobogói balták származhatnak késői sírokból is. Egy-egy viseleti tárgyfajta megléte két temetőben még nem jelenti azt, hogy a viseletük is teljesen azonos volt. A horreumi temetóben két sírban (5. és 9.), a Pusztaszentegyházi dúlőben csak egy sírban (1999/10) került elő együtt ruhatú és fibula. A horreumi temetőben a női és a leánysírok $30 \%$-ában volt tú és $45 \%$-ában fibula. A Pusztaszentegyházi dúlóben viszont a nói és leány sírok 42,4\%-ában volt tú, és mindössze 12,1\%-uk tartalmazott fibulát. A különbség talán a két közösség társadalmi helyzetéból adódott.

A díszítések sem egységesek. A poncolt pontkör díszítést ugyan öt helyről is ismerjük, de csak a Csák-féle temetőben tekinthető jellemzőnek, ahol az alig tucatnyi sírból legalább háromban előfordult. ${ }^{164} \mathrm{~A}$ horreumi temetőben a gúlacsüngős függőn (18. sír) fordul elő. A D-i erôdfal előtti temetőben a két pont-körös díszú szvasztika fibulán ${ }^{165}$ a pont-kör együtt fordul elő a félkör alakú poncolt díszekkel, és éppen ezek keltezik óket a kora avar korra, ${ }^{166}$ egy karperecen ${ }^{167}$ pedig alig ismerhető fel a motívum. A dobogói temetó-

${ }^{162}$ A Lipp-féle temető I. sírjának kardjáról feltételeztem, hogy germán spatha lehetett (MüLLER 2010, 227-228). A tárgy irodalmát lásd CSIKY 2015, 169-170, aki az avar fegyverek közé sorolta (E.I.B/2.a típus).

${ }^{163}$ A Pusztaszentegyházi dúlőből két különböző típus került elő (MÜLleR 2014, 153).

${ }^{164}$ Fettich N. 1951-es munkájának 31. tábláján szereplő tárgyak egy része bizonyosan, vagy nagy valószínúséggel késő római kori (Fеттісн 1951, XXXI. t. 4, 7, 9).

165 VIDA 2018, 171-172 megemlíti még a Pusztaszentegyházi dúlő „, $\mathrm{B}^{\prime \prime}$ sírjában talált szvasztika fibulát, de azt nem pontkör, hanem csak kis sứrún beütögetett körök díszítik, és akárcsak a 2000/100 sírban talált díszítetlen, ezüstözött példány (MÜLLER 2014, 120, Fig. 16), tarsolyból került elő, tehát talizmánként őrzött római kori darabokról lehet szó. A „B” sírba egyébként egy férfit temettek.

166 Vida részletesen foglalkozik a pont-kör díszítéssel és a szvasztika fibulákkal (VIDA 2018, 171-172). Az így díszített tárgyakról feltételezi, hogy vagy "romanizált közösségek átvették és saját viseletükbe illesztették a Meroving kultúrájú germán közösségek által használt tárgyakat ... vagy romanizált környezetbe illeszkedö, akkulturálódott germánokat jelez" ez az anyag. Korábbi elképzeléseimmel ellentétben most úgy vélem, hogy ennek a motívumnak nincs etnikai és kulturális jelentősége (KONCZ-ÓDOR 2016), és csak az egyik fenékpusztai közösség körében volt igazán kedvelt.

167 MÜLLER 2010, Taf. 41, 3, 1967/94. sír. ből csak a Pápa-Úrdomb-típusú csaton és szíjvégen, a Fenéki úti temetóben csak egy aranyozott bronz, pajzs alakú csatrögzítő vereten fordul elő. ${ }^{168}$ A germán tárgyakon gyakori félkör alakú poncolást megtaláljuk a Pusztaszentegyházi dúlói „A" sír övgarnitúráján, egy bronz övvereten és egy bronzcsaton, ${ }^{169}$ a D-i erődfal előtti temető egyik karperecén ${ }^{170}$ és öntött övveretein, ${ }^{171}$ továbbá a diási germán csaton és párhuzamain. ${ }^{172} \mathrm{~A}$ fogazott díszítés a kora avar kor jellegzetes díszítésmódja, ${ }^{173}$ amely csak elvétve fordul elő a korai Keszthely-kultúra anyagában. A Lippféle temető egyik gyürújén, ${ }^{174}$ a Csák-féle temetőben és a dobogói temetóben a helyi készítésúnek tartható, császár apotheosist ábrázoló korongfibulák peremén, a horreumi temetóben a 16. sír övgarnitúrájának ezüstcsatján és a 17. sírban az ezüst lófibula testén, ${ }^{175}$ a pusztaszentegyházi temetőben az egyik övgarnitúra szijvégein ${ }^{176}$ figyelhető meg.

A korai Keszthely-kultúra sírleletei tehát nagyon széles spektrumot ölelnek fel, és egyaránt tartalmazzák a társadalom csúcsán lévő elit és a köznép ékszereit, viseleti tárgyait. Az egyszerú, többnyire bronzból öntött, gúlacsüngős, gömbcsüngős és poliéder végú függők előzményei a provincia késő császárkori emlékanyagában megtalálhatók, a kora avar kori példányokat pannoniai, talán éppen fenékpusztai múhely(ek)ben gyártották. Mint ahogy helyi készítmények lehettek a vasból készült ruhatúk és karperecek is. Ugyancsak késő antik előzményei vannak a kosaras függőknek, az állatfibuláknak, amelyek, akárcsak a korongfibulák, a négyszögletesen megvastagodó szárú ruhatúk és az itáliai (keletalpi) övgarnitúrák Pannonián kívül, főleg a nyugat-mediterrán területeken terjedtek el. Egyes vélemények szerint ezek annak bizonyítékai, hogy a Dunántúl még a korai avar korban is a késó antik kultúrkör része volt, és a tárgyakat a helyben tovább élő késő antik népesség viselte. ${ }^{177}$ Véleményem szerint Fenékpuszta és környéke csak 568-ig lehetett része ennek a kultúrkörnek. A kora avar kori népességen belül a helyben tovább élő késő császárkori lakosság már kisebbséget alkotott, e tárgyak széles körú elterjedése arra utal, hogy ezeket a bevándorlók is viselték.

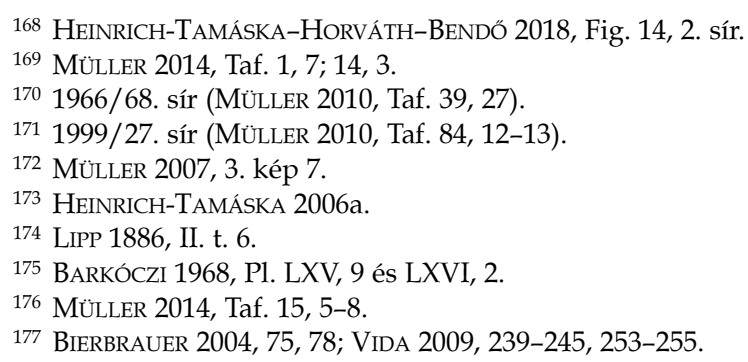


Ez azt is jelenti, hogy 568 után a kelet-alpi, dalmáciai területekról is érkeztek bevándorlók, akik feltehetően a szlávok elől menekültek a jobb megélhetést kínáló avarokhoz, ${ }^{178}$ akik a szállásterületük szélén elhelyezkedő, stratégiailag fontos fenékpusztai erődben és környékén telepítették le őket.

A leletek között vannak a Balkánhoz és a keletmediterrán területhez kötődő tárgyak, mint például a négyszögletes szárú, kövekkel díszített, és a madárfejú ruhatúk, az aláhajtott lábú fibulák, a Yassi Ada-típusú csat, ${ }^{179}$ a csillagcsüngős függő, a hagymafejes övgarnitúra, amelyek a kagán kezdeményezésére ${ }^{180}$ a Balkánról, a bizánci birodalom területéról behurcolt vagy betelepített közösségekkel kerültek ide. Ezek vezetó rétege a kora bizánci ötvösmúvészet olyan remekeit vitték magukkal a sírba, mint a gránáttal díszített gallérdíszt, a félhold csüngójú és az Allachtípusú, arany kosaras függőt, az igazgyönggyel és gránáttal díszített, „BONOSA" feliratú ruhatút, és az ugyancsak igazgyönggyel és gránáttal díszített, hegyikristályos korongfibulát, vagy az architektónikus aranygyürüt. ${ }^{181}$

A germánokhoz köthetó leletek többségét az elit és kísérete által viselt ékszerek, fegyverek, viseleti tárgyak képezik. Ide sorolhatók a bazilika 3. sírjában maradt mellékletek, a Fenéki úti temető 2. sírjából a cloisonné csüngők, az aranygyöngyök, az éremlenyomatok, a Pusztaszentegyházi dúló " $\mathrm{A}$ " sírjából az elvitt díszes spatha, az aranycsat és szíjvég és a pohár peremveret, valamint a mindhárom helyről előkerült, díszes, egyoldalú csontfésúk. Meg kell még említenünk az erőd területéről ismert, különleges, germán leleteket is. ${ }^{182} \mathrm{E}$ tárgyak viselői valószínúleg kisebb csoportokban és különböző germán gensekből érkezett katonák lehettek, ${ }^{183}$ akik abban a reményben csatlakoztak az avarokhoz, hogy a hadjárataikban való részvételért a hadisarcból is részesülnek. A rablások ellenére is gazdag leletek arra utalnak, hogy reményeik teljesültek. A horreumi temetőből is kerültek elő germán fibulák, amelyeket egyesével, a mellkason viseltek, ezért felmerült, hogy a késő antik népesség vette át ezeket, az eredetileg a germánokhoz köthető tárgyakat. ${ }^{184}$ A sírleletek alapján feltételezhető, hogy a

\footnotetext{
178 KISS 1992, 246-247; KISS 2008, 266.

179 VIDA 2009, 253-255.

180 POHL 1988, 112; POHL 2018, 110-111; KONCZ 2015, 333.

181 BARKÓCZI 1968; VIDA 2011.

182 Mindenekelőtt egy fejben végződő tút és egy sisakdísz verőtövét (MÜLLER 2008, 234-237).

183 DAIM 2000, 470; KISS 2008, 266.

184 VIDA 2011, 415. Kétségtelen, hogy a 17. sírban az S-fibulán kívül nemcsak a fogazott díszú lófibula volt a mellkason,
}

germán elit vezető szerepet játszhatott a fenékpusztai közösségek életében, és az alájuk tartozók között megtalálhatók a helyi őslakosok, a máshonnan bevándorolt vagy betelepített családok is. Ugyanakkor az akkulturáció következtében a különböző eredetú tárgyak és helyi utánzataik nemcsak az egyes temetőkben, de egy-egy síron belül is együtt fordulnak elő.

A korai Keszthely-kultúra kezdetét a kutatás általában az 568-as évhez köti. Véleményem szerint a bemutatott 11 temetőból tíz megnyitására csak 568 után kerülhetett sor. Egyedül a D-i erődfal előtti temetőben követhetők folyamatosan nyomon a temetkezések a 4. század közepétól a 7. század első harmadáig-feléig. ${ }^{185}$ A horreumi temetőről még a közelmúltban is felmerült, hogy már 568 előtt megnyitották. Florin Curta szerint Fenékpusztán az 540-es években a Iustinianus kori, al-dunai limes építkezésekhez és a bizáncilangobárd szövetséghez kapcsolódóan kerülhetett sor bizánci missziós tevékenységre, sőt egy bizánci püspökség alapítására. ${ }^{186}$ Nehezen képzelhető el, hogy ez az előkelő közösség 566-ban, amikor II. Iustinus felmondta a szövetséget a langobárdokkal, ${ }^{187}$ Fenékpusztán maradhatott volna. Volker Bierbrauer a római kontinuitás híveként szintén úgy vélte, hogy a horreumi temetőt 568 előtt nyitották meg. ${ }^{188}$ Vida Tivadar szerint is a helyben tovább élő késő antik népesség vezetői temetkeztek a horreum mellé, és az 5., 8., 9. és 30. sír 568 előttre, a 6. század közepe körüli időre keltezhetó. ${ }^{189}$ Ha ez így lenne, és nem az 568 után bevándoroltak temetkeztek ide, mivel magyarázható, hogy alig egy-két évtizeddel az avar honfoglalás elótt a helyi elit így meggazdagodott, és a horreum mellé kezdett temetkezni? Egyébként a sírokban található bizánci készítmények egy része valóban készülhetett 568 előtt, de a félhold alakú csüngős függó javított, a „BONOSA" tú és a hegyi kristályos fibula igazgyöngyei és ékkövei hiányosak, az architektonikus gyứrú nagyon kopott, tehát valószínú, hogy csak több évtizeddel a készítésük után kerültek a földbe. Ezt erősíti meg, hogy az 5. és a 30. sír gyöngysorai a kora avar korra keltezhetók. ${ }^{190}$

\footnotetext{
hanem a koponya körül talált aranycsövecskék az antik elit által viselt hajhálóra utalnak.

185 Az erőd felépülését követően a D-i erődfal teljes hosszában temetkeztek. Az 5. század közepe tájától már csak a D-i erődkaputól Ny-ra eső területet használták (MÜLLER 2010, 242245).

186 CURTA 2002, 57-59; CURTA 2005, 189-191.

187 BÓNA et al. 1993, 110.

188 BIERBRAUER 2004, 73-75.

189 VIDA 2011, 414

190 PÁszTor 2011, 438-439, 441; MÜller 2016, 272, 10. jegyzet.
} 
Újabban a 6. sírt is 568 előttinek tartotta, ${ }^{191} \mathrm{de}$ ez is bizonyosan kora avar kori. ${ }^{192}$ Nem látok okot arra, hogy a horreumi temetó megnyitását 568nál korábbra keltezzük, és az ide temetettekben ne az avar kagán hozzájárulásával betelepítettek vezetőit lássuk.

Ha a Keszthely-kultúrát a hagyományos tárgyak alapján kívánjuk meghatározni, igazat kell adni Volker Bierbrauernak, hogy a Keszthelykultúra korai szakasza 568 előtt kezdődött, ${ }^{193}$ hiszen a ruhatúket és a kosaras függóket a D-i erődkapu előtti temetőben a kora avar kor előtti temetkezésekben is megtaláltuk. De ha a teljes leletanyagot vesszük figyelembe, nyilvánvalóvá válik, hogy a Keszthely környéki kora avar kori, a 6. század utolsó harmadára és a 7. század első harmadára-felére keltezhetô temetők lényegesen eltérnek a többi dunántúli, hasonló korú temető jellemzőitől. Mindenekelőtt nézzük meg, hogy melyek azok a tárgyak, amelyek eddig csak itt kerültek elő. Az antik és bizánci ötvösmúhelyek termékei közül ide sorolhatók a hajhálókat díszítő vékony aranycsövecskék, az ékkővel díszített arany gallérdísz, a négyszögletes fejü, ékkővel díszített ruhatú, ${ }^{194}$ az igazgyönggyel és gránáttal díszített, hegyikristályos korongfibula, a bronzból öntött hagymafejes övgarnitúra, a Balkánról származó aláhajtott lábú, széles kengyelú, ezüstlemezzel díszített vasfibulák. Feltehetően helyi múhelyben készültek a keresztbe bordázott kosárkájú, öntött bronzfüggők, a pont-körrel és félkör alakú ponccal díszített, szvasztika alakú korongfibulák. Meroving múhelyek termékei az arany cloisonné csüngők, a filigránnal díszített aranygyöngyök, az aranylemezes éremlenyomatok, a Pusztaszentegyházi dúlői "A" sír arany övgarnitúrája és aranyozott ezüst pohár peremverete, az aranyozott ezüst madárfej-koszorús fibula (Tierwirbelfibel), az egyszerú, fonott keresztmintás lemezfibula és az erődben talált táncoló fegyvereseket (Waffentänzer) ábrázoló verőtő.

Legalább ilyen hosszú azoknak a tárgyaknak a listája, amelyek az antik és Meroving tradíciókat mutató tárgyakat tartalmazó dunántúli temetőkben előfordulnak, de a korai Keszthely-kultúra temetőiből eddig nem ismertek: koporsót díszítő

\footnotetext{
191 VIDA 2018, 103.

192 A fő érve, hogy a 6. sír gyöngysora késő antik jellegú, és nincsenek benne kora avar kori gyöngyök. Pásztor szerint a bizánci, poncolt aranygyöngy 600 körül készült, és a gyöngysor a 6. század utolsó harmadára keltezhető (PÁszTOR 2011, 439-440).

193 BiERBRAUER 2004, 75.

194 Egyszerúbb változata - ékkő helyett üvegbetéttel - a Pusztaszentegyházi dúlőben került elő.
}

lemezkeresztek, ${ }^{195}$ tausírozott díszú, összecsukható székek (sella plicatilis), ${ }^{196}$ lemezcsüngős nyakékek, ${ }^{197}$ amulettkapszulák, ${ }^{198}$ poncolt és szalagfonatos díszfüggók, ${ }^{199}$ szúrókanalak, ${ }^{200}$ bárdkések (Hackmesser), ${ }^{201}$ lábszárszíj garnitúrák (Wadenbindengarnitur), ${ }^{202}$ csengők, kis harangok, $^{203}$ de nem került eló eddig pajzsdudor ${ }^{204}$ vagy lándzsa sem.

Fenékpuszta és környéke kora avar kori népessége keresztény volt. A sírok temetkezési rítusa mellett az ókeresztény bazilika használata is bizonyítja ezt. A bazilika feltárása nem szolgáltatott egyértelmú adatokat a háromhajós, háromapszisos épület építési idejére vonatkozóan, de az alaprajz analógiái és a két oldalhajóban feltárt sírok megmaradt leletei alapján feltételeztem, hogy erre 568 után került sor. ${ }^{205}$ A 25. épület volt az erődbelső legnagyobb, reprezentációs célokat is szolgáló épülete. Az újabb kutatások alapján három építési periódusa volt, és a harmadikra a 6. század folyamán, ${ }^{206}$ talán már 568 után került sor. Különlegességnek számít az itt talált I. Iustinianus és II. Iustinus ólompecsét. ${ }^{207}$ Bár a korai Keszthely-kultúra vegyes összetételú, a keresztény világgal is kapcsolatokat ápoló népessége az avar birodalom része volt, és ez a keresztény közösség a kagán jóváhagyásával jöhetett létre, a korai Keszthely-kultúra bemutatott temetöiben az avarok etnikailag nem voltak jelen. A mellék-

195 GARAM 2016; VIDA 2018, 20. térkép. Ez azért is érdekes, mert a négy lelőhelyből három a Keszthely-kultúra területének a közelében helyezkedik el (Káptalantót, Kékkút, Zamárdi).

196 VIDA 2018, 183-184, és 24. térkép.

197 GARAM 2001, 45-46.

198 VIDA 2018, 176, 4.2. térkép.

199 VIDA 2018, 161-168, 3.1-3.2. térkép. A Fenéki úti 2. sírban talált kettős, szegecselt aranylemezek egy egészen más típusú, már a langobárdok által is használt típust képviselnek.

200 LŐRINCZY-STRAUB 2005; VIDA 2018, 178-179, 22. térkép.

201 VIDA 2018, 179-180.

202 VIDA 1996, 118-121. Vida a bazilikában előkerült tarsolyzáró csatot és szíjvéget tévesen lábszárszíj veretnek vélte: VIDA 2018, 252 (MÜLLER 2019b, 358).

203 VIDA 2018, 178. A dobogói temetőből ismert egy bronz és egy vascsengő, amelyek lelőkörülményeiről közelebbit nem tudunk (Kiss 1997, 140, 7. tábla 8).

204 A Pusztaszentegyházi dúlőben a „,B” sír tarsolyában volt egy díszes szegecs, amely eredetileg egy pajzsot vagy sax hüvelyt díszített (MÜLLER 2014, 149).

205 MÜlLER 1987, 113-114. HeINRICH-TAMÁSKA 2010, 101-112. tágabb határok között a 6 . század második felére keltezte a bazilika átépítését.

206 HeINRICH-TAMÁSKA-PRIEN 2018, 140-141. Az épület a korai Keszthely-kultúra időszakával megegyezően a 7. század első feléig maradt használatban.

207 HeINRICH-TAMÁSKA-PRIEN 2019, 55, 58, 8-9. Lelőkörülményeit nem közölték, de császárportréval nyilvánvalóan nagy értéket, feltehetóen pénzt hitelesítettek. E két fontos tárgyat akár a balkáni hadjáratok egyike során is megszerezhette egy helyi vezető. 
letek közül éppúgy hiányoznak a jellegzetes avar fegyverek ${ }^{208}$ és tárgyak, ${ }^{209}$ mint a lovas temetkezés. ${ }^{210}$

A 7. század második harmadától-közepétől kezdődött egy átmeneti időszak, amikor a fenékpusztai erőd elpusztítását követően a gazdag elit eltúnt. A korai Keszthely-kultúra népessége avar katonai felügyelet alá került, ${ }^{211}$ az erőd életben maradt köznépi tagjait feltehetően áttelepítették a mai Keszthely területére, és megnyitották a városi- vagy sörházkerti temetőt, amelybe térben elkülönülve együtt temetkeztek a keresztények és a pogány avarok. ${ }^{212} \mathrm{Az}$ elit eltúnésével a relatív függetlenséget elveszítették, a keresztény Európával fenntartott kapcsolatok is meggyengültek. ${ }^{213}$ De a keresztény vallásnak köszönhetôen ${ }^{214}$ ez a vegyes összetételú közösség meg tudta tartani különállását, és nem olvadt be az avarságba. Az általuk előállított kézmúipari és agrártermékekre ${ }^{215}$ az avarság továbbra is igényt tartott, és ha a korábbi gazdagság meg is szúnt, de egy-egy aranytárgy és az ezüst kosaras függók sora arra utalnak, hogy a Keszthely-kultúra

${ }^{208}$ A Lipp-féle temetőből előkerült kétélű kardot Bóna (BóNA 1982-83, 119), Heinrich-Tamáska (HeINRICH-TAMÁsKa 2008, 440) és Csiky (CsiKY 2015, 169, E.I.B/2a típus) K-i eredetúnek határozták meg. Én elképzelhetónek tartottam, hogy germán spatháról van szó (MÜLLER 2010, 227).

${ }^{209}$ Ritka kivétel a Pusztaszentegyházi dúlő egyik legkésőbbi sírjából (2000/155) előkerült csont bogozó (MÜLLER 2014, Taf. $27,8)$.

${ }^{210}$ A dobogói temetőben talált lovas sírokról ld. 126. jegyzet. A Fenékpusztán, a Lipp-féle temető leleteként közölt, voltaképp a páhoki (hévízi) temetőből származó zablatöredékből Bóna (BÓNA 1982-83, 118) szimbolikus lovas sírra következtetett, amire nem ismerünk példát az avar korból, HeinrichTamáska (HeINRICH-TAMÁSKA 2008, 440) pedig tévesen lószerszám mellékletet említ. Lásd még: MÜLLER 2012, 46-48.

211 MÜlLER 1989, 162-164.

212 KovRIG 1958, 72-74.

${ }^{213} \mathrm{Az}$ erőd pusztulása utáni kapcsolat fennmaradására utal a bizánci csatok megjelenése a Keszthely-kultúra temetőiben. A Kárpát-medence egyetlen eredeti Korinthosz-típusú csatja Keszthelyen került eló (HAMPEL 1905 I. 300, Fig. 734). A 7. század második harmadától kezdődően bizánci mintára a Keszthely-kultúra bronzipara is gyártott ilyen csatokat (MÜLLER 2020).

${ }^{214}$ Kétségtelen, hogy a késői sírok leletei között ritkák a keresztény jellegú tárgyak, és a lesencetomaji temetőből ismert három kereszt is vitatott értelmezésú (S. PERÉMI 2012), de egy-egy kerámia vagy pántos favödör feltúnése a mellékletek között még nem bizonyítja, hogy a Keszthely-kultúra népessége pogány volt (MÜLLER 2019, 330-331).

215 A fenékpusztai erőd környékén végzett pollenvizsgálatok azt mutatták, hogy a 7. század közepétől a földmúvelés visszaszorult, és a területen állattartást folytattak (HEINRICHTAMÁSKA 2008, 436). Elképzelhető, hogy a lakatlan erőd környékét a távolság miatt nem múvelték meg, de a késó Keszthely-kultúra nagy sírszámú temetői alapján olyan népsúrúséggel kell számolnunk, amit csak intenzív földmúveléssel lehetett eltartani (MÜLLER 2019a, 330-331). népessége nem szegényedett el teljesen. Saját bronzipara révén el tudta készíteni a különleges viselethez szükséges tárgyakat, a speciális ékszereket. A kultúra népessége végleg elszigetelődött a 7. század utolsó harmadától, amikor a közép avar időszakban a birodalom nyugat felé terjeszkedett, és a Keszthely-kultúra a peremról a birodalom belsejébe került. Ebben az átmeneti időszakban - pl. a 7. század közepén megnyitott Lesencetomaj-Piroskereszt-i temetőben - még megtaláljuk a kis méretú, áttört kosárkás függóket, a viszonylag rövid madárfejben vagy karikában végződő ruhatúket, az S-alakú díszítetlen madárfibulát. ${ }^{216}$ A kora avar kor sokrétú anyagi múveltsége a 8 . század folyamán egységessé vált (griffes-indás avarok). Ugyanez figyelhető meg a Keszthely-kultúra késői fázisában. Minden temetóben általánossá váltak az egyre nagyobb méretú, elöl zárt, hátul áttört kosarú függók, amelyek karikáját elöl rombusz vagy négyszög alakban ellapították, és kőberakással, granulációval díszítették, az egyre hosszabbá váló ruhatǔk, amelyek szára négyágúvá hasított, és poncolt díszítésú, a kőberakást imitáló préselt korongfibulák ${ }^{217}$ és a lemezes, kígyófejes karperecek. ${ }^{218}$ Ezek a tárgyak kizárólag Keszthely körül, a Kéthely-HévízLesencetomaj háromszög területén fordulnak elő, ezért méltán viselik a késői Keszthely-kultúra elnevezést, és egyértelmú, hogy a korai fázisból alakultak ki. ${ }^{219}$

\section{Összegzés}

A korai Keszthely-kultúra meghatározására nem elegendő a korábbi kritériumok - a kosaras függők, a ruhatúk és korongfibulák - figyelembevétele. A fenékpusztai eród területéról és környékéről hét olyan temetôt ismerünk, amelyeket a 6. század utolsó és a 7. század első harmadában használtak. Ezekkel lehet egyidős a szigligeti lelet és három nagy sírszámú temető, amelyeket ugyancsak a 6. század utolsó harmadában nyitottak meg, de folyamatosan használtak az avar kor végéig. A fenékpusztai temetők közül csak a D-i erődfal előttiben figyelhető meg előzmény, itt a

216 S. PERÉMI 2008.

217 S. PERÉMI 2014.

218 Emellett feltúnnek a késő avar kori női ékszerek is, mint az üveggyöngy-csüngős függők, a dinnyemag alakú gyöngyök, a huzalkarperecek stb., de érthető módon nem veszik át a varkocsszorítókat és a boglárpárokat sem.

219 A három folyamatosan használt temető mellett kilenc olyan, feltehetóen ugyancsak nagy sírszámú temetőről vannak adataink, amelyek a Keszthely-kultúra késő fázisára keltezhetők. Megválaszolatlan a kérdés, hogy kik használták ezeket a temetőket, mert ennyien nem élhettek az erődben. 


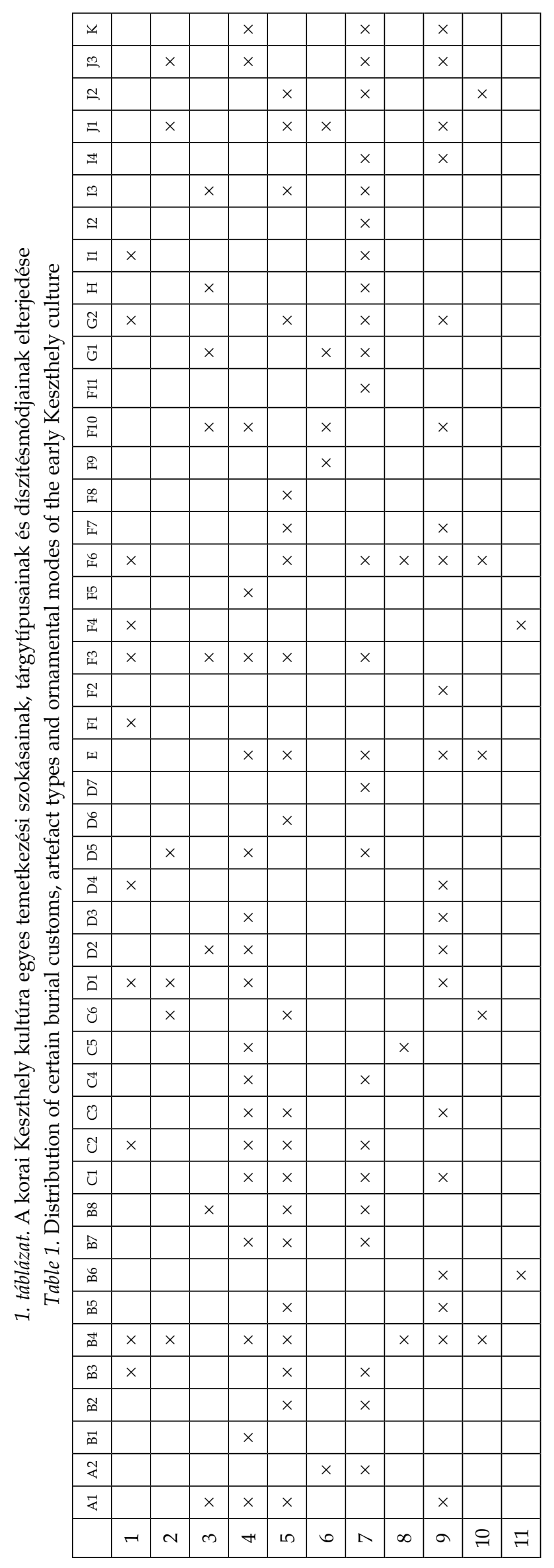

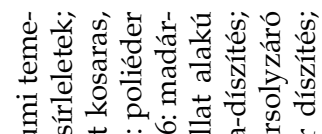

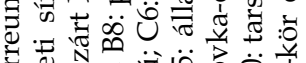
g.

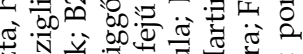

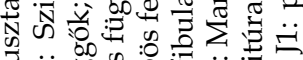

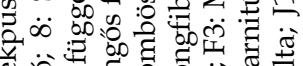

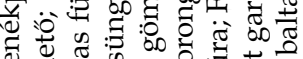

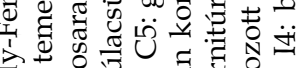

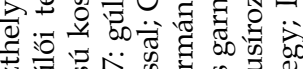

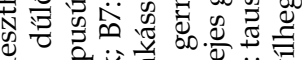

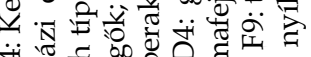

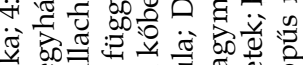

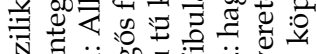

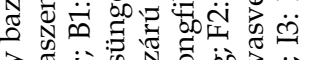

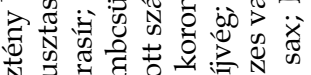

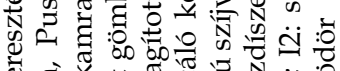

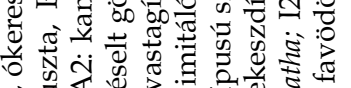

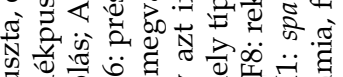

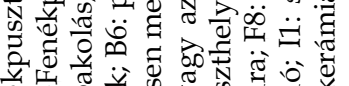

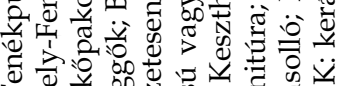

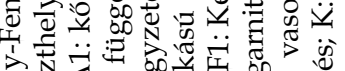

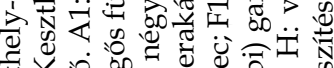

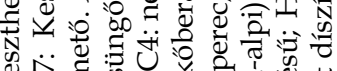

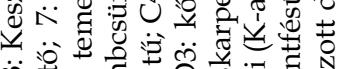

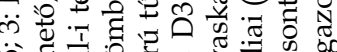

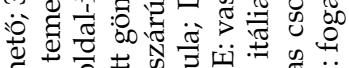

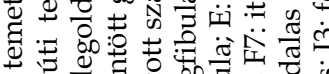

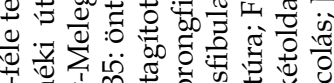

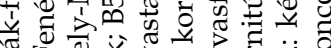

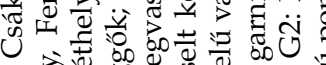

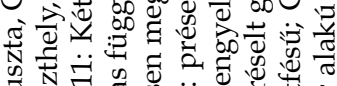

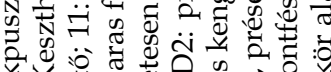

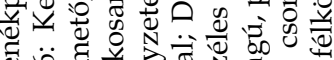

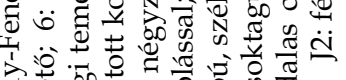
要

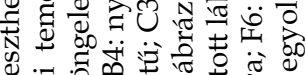

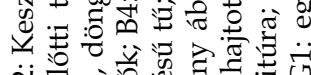

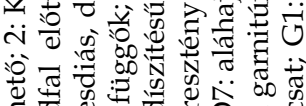

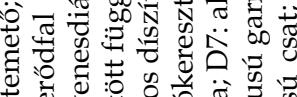

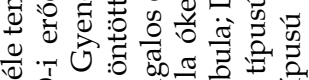

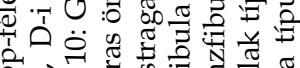

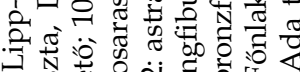

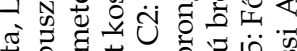

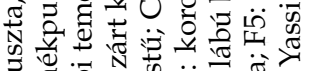

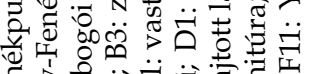

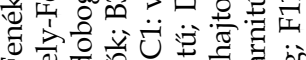

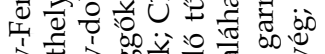

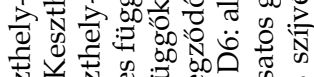

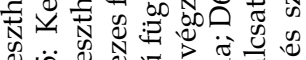
舟

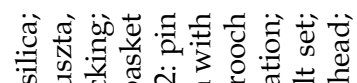
象

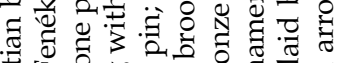

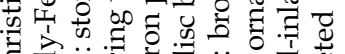

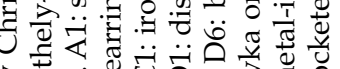

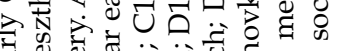

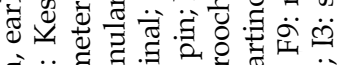

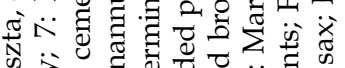
窟西

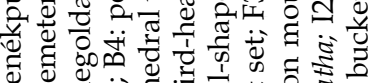
它

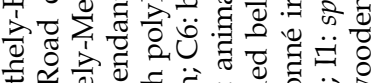

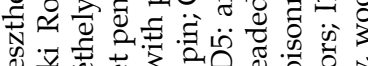

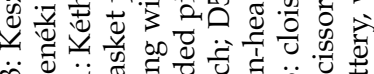

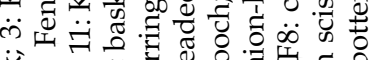

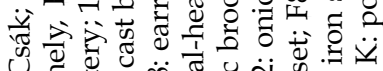
o

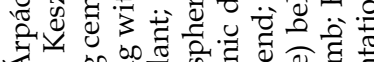

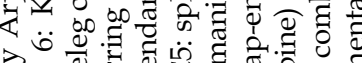

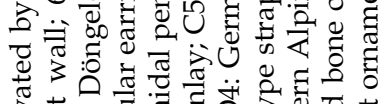

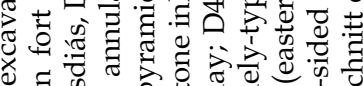

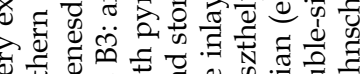

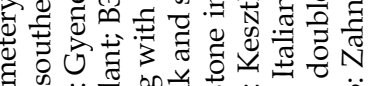

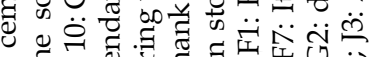

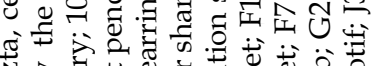

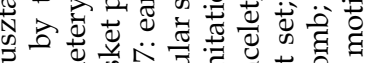

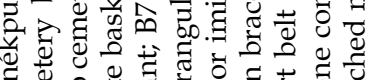

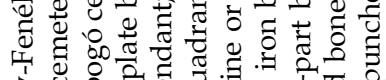
传

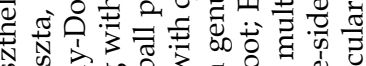

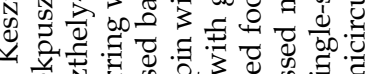

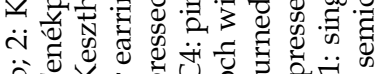
究语记 定市

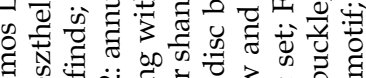
今.

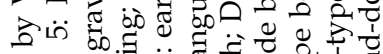

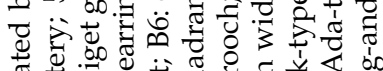

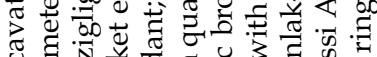

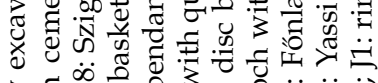

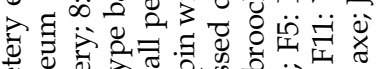

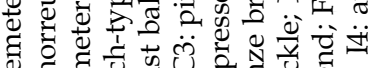

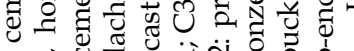
我语:

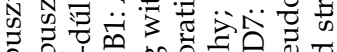

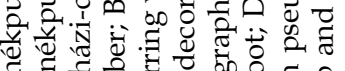
क्षे

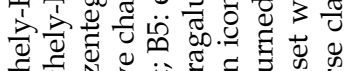

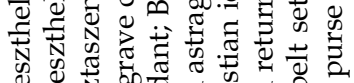

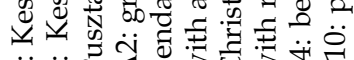


4. század közepétól a 7. század első harmadáigfeléig folyamatosan temetkeztek. Ez is megerósíti a feltételezést, hogy az erőd kora avar kori népességének a többségét a bevándoroltak alkották. A temetők nagy száma, és az egyezések mellett fennálló különbségek - a különböző nyugatés kelet-mediterrán, kora bizánci, balkáni és a germán Meroving-tárgyak (1. táblázat) - alapján a betelepített, bevándorolt közösségek különböző helyekről, és különböző időpontokban jelentek meg. Kelet-alpi, dalmáciai területről a szlávok elől menekülők, a Balkánról behurcoltak és betelepültek, germán területről katonai csoportok érkezhettek. A tárgyi anyag több olyan típust tartalmaz, ami a dunántúli, kora avar kori temetőkből nem ismert, illetve olyan típusokat, amelyek ott megvannak, de itt hiányoznak. Ezért ezt a vegyes összetételú, keresztény népességet, amelynek temetőiben az avarok etnikailag nem voltak jelen a Keszthely-kultúra korai fázisának kell nevezni. A 7. század második felétől fokozatosan alakul át a tárgyi anyag, és a 8 . századra létrejön a Keszthely-kultúra késői fázisa.

\section{IRODALOM}

ALFÖLDI, ANDRÁS

1926 Der Untergang der Römerherrschaft in Pannonien 2. Berlin-Leipzig.

BAKAY KORNÉL-KALICZ NÁNDOR-SÁGI KÁROLY

1966 Veszprém megye régészeti topográfiája. A keszthelyi és tapolcai járás. In: Sági K. (szerk.): Magyarország régészeti topográfiája 1 . Budapest.

BÁLINT, CSANÁD

1993 Probleme der archäologischen Forschung zur awarischen Landnahme. In: Müller-Wille, M.-Schneider, R. (Hrsg.): Ausgewählte Probleme europäischer Landnahmen des Früh- und Hochmittelalters. Sigmaringen, 196-273.

2019 The Avars, Byzantium and Italy. A Study in Chorology and Cultural History. Varia Archaeologica Hungarica 31. Budapest.

BARKÓCZI, LÁSZLÓ

1968 A 6th Century Cemetery from Keszthely-Fenékpuszta. Acta Archaeologica Academiae Scientiarum Hungaricae (Budapest) 20, 275-311.

1971 Das Gräberfeld von Keszthely-Fenékpuszta aus dem 6. Jahrhunderts und die frühmittelalterlichen Bevölkerungsverhältnisse am Plattensee. Jahrbuch des Römisch-Germanischen Zentralmuseums (Mainz) 18, 179-191.

1994 Beiträge zur Geschichte der Provinz Valeria im IV.-VI. Jahrhundert. Specimina Nova (Pécs) 10, 57-135.

BARKÓCZI, LÁSZLÓ-SALAMON, ÁGNES

1984 Tendenzen der strukturellen und organisatorischen Änderungen pannonischer Siedlungen im 5. Jahrhundert. Alba Regia (Székesfehérvár) 21, 147-187.

BENDÓ, ZsOlt-HeinRich-TAMÁSKA, ORSOLYA-HORVÁTH, EsZTER

2014 Material- und Herstellungsanalysen der goldenen und vergoldeten Metallfunde aus dem Grab A von Keszthely-Fenékpuszta, Ödenkirche-Flur. In: Müller, R.: Die Gräberfelder von Keszthely-Fenékpuszta, Ödenkirche-Flur. Castellum Pannonicum Pelsonense 5. Budapest-Leipzig-Keszthely-Rahden, 311-355.

BIERBRAUER, VOLKER

2004 A Keszthely-kultúra és a késő római továbbélés kérdése Pannoniában (Kr. u. 5-8. század). Újabb gondolatok egy régi problémáról. Archaeologiai Értesítő (Budapest) 129, 67-82.

BLAY, ADRIENN

2018 Überlegungen zur Bedeutung und Gültigkeit des Begriffs „Keszthely-Kultur”. Antaeus (Budapest) BOLLÓK, ÁDÁM 35-36, 167-186.

2014 Bellerophon and Cricifixion? A brief note on late antique circular box brooches from Pannonia. In: Heinrich-Tamáska, O.-Straub, P. (Hrsg.): Mensch, Siedlung und Landschaft im Wechsel der Jahrhunderte am Balaton. Castellum Pannonicum Pelsonense 4. Budapest-Leipzig-Keszthely-Rahden, 259-279.

BÓNA, ISTVÁN

1961-62 Beiträge zu den ethnischen Verhältnissen des 6.-7. Jahrhunderts in Westungarn. Alba Regia (Székesfehérvár) 2-3, 49-68.

1970 Avar lovassír Iváncsáról. Archaeologiai Értesítő (Budapest) 97, 243-261.

1971 Ein Vierteljahrhundert Völkerwanderungszeit Forschung in Ungarn (1945-1969) Acta Archaeologica Academiae Scientiarum Hungaricae (Budapest) 23, 265-336.

1982-83 A XIX. század nagy avar leletei (Die grossen Awarenfunde des 19. Jahrhunderts) Szolnok Megyei Múzeumi Évkönyv (Szolnok), 81-160.

Bóna István-Cseh János-Nagy Margit-Tomka Péter-Tóth Ágnes

1993 Hunok - gepidák - langobardok. Szeged. 
CURTA, FLORIN

2002 Limes and cross: The religious dimension of sixth-century Danube Frontier of the Early-Byzantine Empire. Starinar (Beograd) 51, 45-70.

2005 Before Cyril and Methodius: Christianity and Barbarians beyond the Sixth- and Seventh-Century Danube Frontier. In: Curta, F. (eds): East Central Europe in the Middle Ages. Ann Arbor, 181-219.

CSÁK ÁRPÁD

1903 Fenék (Mogentiana) és területén az 1899. év folyamán teljesített első archaeológiai ásatásunk eredményeinek ismertetése. Balatoni Múzeum Egyesület első Évkönyve (Keszthely), 73-92.

CSALLÁNY, DEZSŐ

1956 Archäologische Denkmäler der Awarenzeit in Mitteleuropa. Budapest.

CSIKY, GERGELY

2015 Avar-Age Polearms and Edged Weapons. Classification, Typology, Chronology and Technology. East Central and Eastern Europe in the Middle Ages, 450-1450, Vol. 32, Leiden-Boston.

DAIM, FALKO

2000 Keszthely. RGA² 16. Berlin-New York, 468-474.

2002 Pilgeramulette und Frauenschmuck? Zu den Scheibenfibeln der frühen Keszthely-Kultur. Zalai Múzeum (Zalaegerszeg) 11, 113-144.

2003 Avars and Avar Archaeology: An Intropduction. In: Goetz, H.-W.-Jarnut, J.-Pohl, W. (eds): Regna and Gentes: The Relationship between Late Antique and Early Medieval Peoples and Kingdoms in The Transformation of the Roman World. The Transformation of the Roman World 13. Leiden-Boston, 463-595.

DARNAY KÁLMÁN

1901 Sümeghvidéki emlékek a régibb középkorból. Archaeologiai Értesítő (Budapest) 21, 176-182.

DORNYAY BÉLA

1941 Diás népvándorláskori leleteiról. Balatoni Múzeum Értesítője (Keszthely) 1, 32-35.

FETTICH NÁNDOR

1951 Régészeti tanulmányok a késői hun fémmúvesség történetéhez (Archäologische Studien zur Geschichte des späthunnischen Metallkunst). Archaeologia Hungarica 31. Budapest.

GARAM, ÉVA

1991 Über Halsketten, Halsschmuck mit Anhängern und Juwelenkragen byzantinischen Ursprungs aus der Awarenzeit. Acta Archaeologica Academiae Scientiarum Hungaricae (Budapest) 43, 151-179.

1993 Die awarenzeitlichen Scheibenfibeln. Communicationes Archaeologicae Hungariae (Budapest) 99-134.

2001 Funde byzantinischer Herkunft in der Awarenzeit vom Ende des 6. zum Ende des 7. Jahrhunderts. Monumenta Avarorum Archaeologica 5. Budapest.

2016 A zamárdi avar kori temető lovassírjai (Horse burials of the Avar cemetery at Zamárdi). In: Kovács L.Révész L. (szerk.): Népek és kultúrák a Kárpát-medencében. Tanulmányok Mesterházy Károly tiszteletére. Budapest, 2016, 271-286.

GLASER, FRANZ

2002 Bildmotive der Scheibenfibeln aus Keszthely. Zalai Múzeum (Zalaegerszeg) 11, 145-152.

HAMPEL, JÓZSEF

1905 Alterthümer des frühen Mittelalters in Ungarn I-III. Braunschweig.

HEINRICH-TAMÁSKA, ORSOLYA

2006a Die Stein- und Glasinkrustationskunst des 6. und 7. Jahrhunderts im Karpatenbecken. Monumenta Avarorum Archaeologica 8. Budapest.

2006b Tier- und Zahnschnittornamentik im awarenzeitlichen Karpatenbecken. Bericht der RömischGermanischen Kommission (Frankfurt am Main) 87, 505-627.

2008 Bemerkungen zur Landschafts- und Raumstruktur auf dem Gebiet der Keszthely-Kultur. In: Bemmann, J.-Schmauder, M. (Hrsg.): Kulturwandel in Mitteleuropa. Langobarden - Awaren - Slawen. Kolloquien zur Vor- und Frühgeschichte 11. Bonn, 431-447.

2010 Sakral- oder Profanbauten? Zur Funktion und Datierung der „Kirchen” von Keszthely-Fenékpuszta (Komitat Zala, Ungarn). In: Krohn, N. (Hrsg.): Kirchenarchäologie heute. Fragestellungen - Methoden - Ergebnisse. Darmstadt, 91-112.

2016 Templomok és keresztény közösségek Észak-Illyricum (Pannonia és Noricum) területén a római kontinuitás tükrében (Kr. u. 5-7. század). In: Tóth E.-Vida T.-Takács I. (szerk.): Szent Márton és Pannónia. Kereszténység a római világ határán. Pannonhalma-Szombathely, 123-136.

HEINRICH-TAMÁSKA, ORSOLYA-HORVÁTH, ESZTER-BENDÓ, ZSOLT

2018 Before or after 568 AD? Technological observations on the gold objects from Grave 2 at Keszthely-Fenéki Street. In: Eilbracht, H.-Heinrich-Tamáska, O.-Niemeyer, B.-Reiche, I.-Voß, H.-U. (Hrsg.): Über den glanz des Goldes und die Polychromie. Technische Vielfalt und kulturelle Bedeutung vor- und frühgeschichtlicher Metallarbeiten. Kolloquien zur Vor- und Frühgeschichte 24. Bonn, 313-334.

HEINRICH-TAMÁSKA, ORSOLYA-PRIEN, ROLAND

2018 Keszthely-Fenékpuszta in der Spätantike: ein Vorbericht über die deutsch-ungarischen Ausgrabungen zwischen 2009 und 2017. Antaeus (Budapest) 35-36, 119-145.

2019 Castrum Virtuale. Időutazás a fenékpusztai római erődben. Kiállításkatalógus, Keszthely-Leipzig. 
HEINRICH-TAMÁSKA, ORSOLYA-SYRBE, DANIEL

2016 "Grenzübergänge" zwischen 300 und 800 n. Chr. Einführende Betrachtungen zu den globalen und lokalen Vegflechtungen des Mitteldonauraumes. In: Bugarski, I.-Heinrich-Tamáska, O.-Ivanišević, V.Syrbe, D. (eds): GrenzÜbergänge. Spätrömisch, frühchristlich, frühbyzantinisch als Kategorien der historisch-archäologischen Forschung an der mittleren Donau. Remshalden, 11-39.

H. KELEMEN, MÁRTA

2008 Solva. Esztergom késő római temetői (Solva. Die spätrömischen Gräberfelder von Esztergom). Libelli Archaeologici Ser. Nov. 3, Budapest.

Kiss ATtILA

1968 A Keszthely-kultúra helye a pannóniai római kontinuitás kérdésében (The Place of the KeszthelyCulture in the Problem of the Roman Continuity in Pannonia). Archaeologiai Értesítő 95, 93-102.

1992 Germanen im awarenzeitlichen Karpatenbecken. In: Daim, F. (Hrsg.): Awarenforschungen I. Studien zur Archäologie der Awaren. Wien 1992, 35-134.

1996 Das awarenzeitlich gepidische Gräberfeld von Kölked-Feketekapu A. Monographien zur Frühgeschichte und Mittelalterarchäologie 5. Innsbruck.

KISS GÁBOR

1997 A Keszthely-dobogói avar kori temetó (Lipp Vilmos ásatása) (Das awarische Gräberfeld von KeszthelyDobogó). Zalai Múzeum (Zalaegerszeg) 8, 115-160.

2008 Der Wandel im archäologischen Nachlass der Keszthely-Kultur im Laufe des 7. und 8. Jahrhunderts. Versuche zur Periodisierung. Antaeus 29-30, 2008, 265-277.

2011 Die Entstehung und Anwendung des Keszthely-Kultur-Begriffs aus froschungsgeschichtlicher Sicht. In: Heinrich-Tamáska, O. (Hrsg.): Keszthely-Fenékpuszta im Kontext spätantiker Kontinuitätsforschung zwischen Noricum und Moesia. Castellum Pannonicum Pelsonense 2. Budapest-Leipzig-KeszthelyRahden, 509-540.

KONCZ, ISTVÁN

2015568 - A historical date and archaeological consequences. Acta Archaeologica Academiae Scientiarum Hungaricae (Budapest) 66, 315-340.

KONCZ, ISTVÁN-ÓdOR, JÁNOS GÁBOR

2016 Einfach oder anspruchslos? Über das Punktkreisornament im 6. Jahrhundert anhand dreier Fibeln aus dem Komitat Tolna. Archaeologiai Értesítő (Budapest) 141, 145-156.

KovRig ILONA

1958 Megjegyzések a Keszthely-kultúra kérdéséhez (Bemerkungen zur Frage der Keszthely-Kultur). Archaeologiai Értesítő (Budapest) 85, 66-74.

1960 Újabb kutatások a keszthelyi avar kori temetőben (Neue Forschungen im frühmittelelterlichen Gräberfeld von Keszthely. Archaeologiai Értesítő (Budapest) 87, 136-169.

\section{KÖLTŐ LÁSZLÓ}

1991 A Kéthely-melegoldali Keszthely-kultúrás temető (Előzetes jelentés) (Ein Gräberfeld der KeszthelyKultur von Kéthely-Melegoldal (Vorbericht)). A Móra Ferenc Múzeum Évkönyve (Szeged) 1984-85, 171-186.

KUZSINSZKY BÁLINT

1920 A Balaton környékének archaeológiája. Budapest.

LINDENSCHMIT, LUDWIG

1889 Handbuch der deutschen Altertumskunde I: die Altertümer der merowingischen Zeit. Braunschweig.

LipP VILMOS

1884 A keszthelyi sírmezők. Budapest.

1886 A fenéki sírmező. Archaeologiai Közlemények (Budapest) 14, 137-159.

LŐRINCZY GÁbOR-STRAUb PÉTER

2005 Újabb adatok az avar kori szűrőkanalak értékeléséhez III (Neue Angaben zur Bewertung der awarenzeitlichen Sieblöffel) A Móra Ferenc Múzeum Évkönyve - Studia Archaeologica (Szeged) 11, 127-145.

MÜLleR RÓBERT

1987 Megjegyzések Fenékpuszta történetéhez (Bemerkungen zur Geschichte von Fenékpuszta). Zalai Múzeum (Zalaegerszeg) 1, 105-122.

1989 Die Keszthely-Kultur. In: Müller, R. (Hrsg.): Sieben Jahrtausende am Balaton. Von der Ur- und Frühgeschichte bis Ende der Türkenkriege. Mannheim, 64-71.

1992 Neue archäologische Funde der Keszthely-Kultur. In: Daim, F. (Hrsg.): Awarenforschungen I. Studien zur Archäologie der Awaren 4. Wien, 251-307.

1996a Keszthely kultúra. In: Költő L.-Vándor L. (szerk.): Évezredek üzenete a láp világából. Régészeti kutatások a Kis-Balaton területén 1979-1992. Kaposvár-Zalaegerszeg, 98-102.

1996b Über die Herkunft und das Ethnikum der Keszthely-Kultur. In: Bialeková, D.-Zábojník, J. (Hrsg.): Ethnische und kulturelle Verhältnisse an der mittleren Donau vom 6. bis zum 11. Jahrhundert. Bratislava, 75-82. 
1999 Sági Károly temetőfeltárása a Keszthely-fenékpusztai erőd déli fala előtt (1963-1967). Zalai Múzeum (Zalaegerszeg) 9, 153-179.

2000a Ein germanisches Grab der Frühawarenzeit aus Keszthely-Fenékpuszta. Acta Archaeologica Academiae Scientiarum Hungaricae (Budapest) 51, 351-366.

2000b Balatongyörök régészeti leletei. In: Molnár A. (szerk.): Balatongyörök múltja és jelene. Balatongyörök, 12-36.

2002 Das Familiengräberfeld Keszthely, Fenéki-Straße. In: Germanen am Plattensee. Katalog des NÖ Landesmuseums, N. F. 438. Traismauer, 33-35.

2007 Gyenesdiás régészeti leletei. In: Molnár A.-Gál L. (szerk.): Gyenesdiás Nagyközség Monográfiája I. Gyenesdiás története, Gyenesdiás, 15-45.

2008 Neue germanische Funde aus der Festung Keszthely-Fenékpuszta. Acta Archaeologica Academiae Scientiarum Hungaricae (Budapest) 59, 231-245.

2010 Die Gräberfelder vor der Südmauer der Befestigung von Keszthely-Fenékpuszta. Castellum Pannonicum Pelsonense 1, Budapest-Leipzig-Keszthely-Rahden.

2012 Lipp Vilmos és Csák Árpád temetőfeltárásai Fenékpusztán. In: Vida T. (szerk.): Thesaurus Avarorum. Régészeti tanulmányok Garam Éva tiszteletére. Budapest, 37-61.

2014 Die Gräberfelder von Keszthely-Fenékpuszta, Ödenkirche-Flur. Castellum Pannonicum Pelsonense 5, Budapest-Leipzig-Keszthely-Rahden.

2016 Spätantike Elemente in den Gräberfeldern der frühen Keszthely-Kultur. In: Bollók, Á.-Csiky, G.Vida, T. (Hrsg.): Zwischen Byzanz und der Steppe. Archäologische und historische Studien für Csanád Bálint zum 70. Geburtstag. Budapest, 271-289.

2019a Gibt es noch eine Keszthely-Kultur? In: Farkas, G. I.-Neményi, R.-Szabó, M. (eds): Visy 75 artificem comendat opus. Studia in honorem Zsolt Visy. Pécs, 325-337.

2019b Opponensi vélemény Vida Tivadar: A sztyeppei, a bizánci és Meroving birodalmak között, kulturális változások a Kárpát-medence nyugati felén a 6-7. században címú a MTA doktora fokozat elnyerésére benyújtott disszertációjáról. Zalai Múzeum (Zalaegerszeg) 24, 355-361.

2020 „Bizánci” csat Zalaegerszeg-Kaszaházáról. Pannon Tükör (Zalaegerszeg) 25/2, 65-71.

NAGY LAJOS

1938 Pannonia sacra. Szent István Emlékkönyv I, Budapest, 31-148.

NAGY, MARGIT

2002 Synkretistische Elemente in der frühawarenzeitlichen Ornamentik. Zur Frage der awarenzeitlichen Variante des Motivs „Maske bzw. Menschengesicht zwischen zwei Tieren”. Zalai Múzeum (Zalaegerszeg) 11, 153-178.

\section{PÁSZTOR, ADRIEN}

2010 Die Perlenfunde aus den Gräbern der Keszthely-Kultur in der Nekropole vor der Südmauer der Befestigung Keszthely-Fenékpuszta. In: Müller, R. (Hrsg.): Die Gräberfelder vor der Südmauer der Befestigung von Keszthely-Fenékpuszta. Castellum Pannonicum Pelsonense 1. Budapest-LeipzigKeszthely-Rahden, 349-374.

2011 Auswertung der Perlen aus dem Gräberfeld Keszthely-Fenékpuszta, Horreum. In: Heinrich-Tamáska, O. (Hrsg.): Keszthely-Fenékpuszta im Kontext spätantiker Kontinuitätsforschung zwischen Noricum und Moesia. Castellum Pannonicum Pelsonense 2. Budapest-Leipzig-Keszthely-Rahden, 438-442.

2014 Perlenfunde aus dem frühawarenzeitlichen Gräberfeld von Keszthely-Fenékpuszta, Ödenkirche-Flur. In: Müller, R. (Hrsg.): Die Gräberfelder von Keszthely-Fenékpuszta, Ödenkirche-Flur. Castellum Pannonicum Pelsonense 5, Budapest-Leipzig-Keszthely-Rahden, 257-310.

PeKÁRY TAMÁs

1955 Későrómai sírok Fenékpusztán (Spätrömische Gräber in Fenékpuszta). Archaeologiai Értesítő (Budapest) 82, 19-29.

S. PerÉmi ÁGota

2000 A Lesencetomaj-Piros kereszt Keszthely-kultúrás temető fülbevalói (Burial Earrings of the LesencetomajPiros kereszt Keszthely Culture). A Veszprém megyei Múzeumok Közleményei (Veszprém) 21, 41-75.

2008 Lesencetomaj-Piroskereszt, Komitat Veszprém. In: Hegewisch, M. (Red.): Die Langobarden. Das Ende der Völkerwanderung. Bonn, 329-338.

2012 Keresztmellékletes sírok a Lesencetomaj-Piroskereszt temetóból (Gräber mit Kreuzbeigaben im Gräberfeld von Lesendetomaj-Piroskereszt). In: Vida T. (szerk.): Thesaurus Avarorum. Régészeti tanulmányok Garam Éva tiszteletére. Budapest, 437-476.

2014 Die Scheibenfibeln aus dem Keszthely-Kultur-Gräberfeld von Lesencetomaj-Piroskereszt. In: HeinrichTamáska, O.-Straub, P. (Hrsg.): Mensch, Siedlung und Landschaft im Wechsel der Jahrtausende am Balatom. Castellum Pannonicum Pelsonense 4. Budapest-Leipzig-Keszthely-Rahden, 223-258.

2016 A lesencetomaji temető. In: Tóth E.-Vida T.-Takács I. (szerk.): Szent Márton és Pannónia. Kereszténység a római világ határán. Pannonhalma-Szombathely, 143-144. 
POHL, WALTER

1988 Die Awaren. Ein Steppenvolk in Mitteleuropa 567-822 n. Chr. München.

2018 The Awars. A Steppe Empire in Central Europe, 567-822. Ithaka-New York-London.

RHÉ GYULA

1924 Veszprém vármegyei avar emlékek. Közlemények Veszprémvármegye múltjából 2. Veszprém.

SÁGI, KÁROLY

1961 Die zweite altchristliche Basilika von Keszthely-Fenékpuszta. Acta Antiqua (Budapest) 9, 397-451.

1981 Das römische Gräberfeld von Keszthely-Dobogó. Fontes Archaeologici Hungariae, Budapest.

1989 Adatok a fenékpusztai erőd történetéhez - Über die Geschichte der Festung in Fenékpuszta. A Tapolcai Városi Múzeum Közleményei (Tapolca) 1, 1989 (1990), 261-317.

1991 Egy VI. századi keszthelyi temető és mondanivalója a „Keszthely kultúra” etnikuma szempontjából (Keszthelyer Friedhof aus dem 6. Jahrhundert und dessen Bedeutung bezüglich des Ethnikums der „Keszthely-Kultur”). A Tapolcai Városi Múzeum Közleményei (Tapolca) 2, 113-141.

SAMU, LEVENTE-DAIM, FALKO

2018 Die Pseudoschnallen in der Awarenzeit und ihre Transformation. Antaeus (Budapest) 35-36, 205-241.

STRAub PÉTER

1999 A Keszthely kultúra kronológiai és etnikai hátterének újabb alternatívája (Die neuere Alternative des chronologischen und ethnischen Hintergrundes der Keszthely-Kultur). Zalai Múzeum (Zalaegerszeg) 9, 195-224.

2000 6-7. századi temetőrészlet Keszthely-Fenékpusztán (Erdélyi István ásatása, 1976) (Gräber aus dem 6. und 7. Jahrhundert in Keszthely-Fenékpuszta (Die Ausgrabungen von István Erdélyi, 1976). In: Bende L.-Lőrinczy G.-Szalontai Cs. (szerk.): Hadak útján, Szeged, 205-229.

2002 Eine frühawarenzeitliche Taubenfibel mit christlichem Symbol von Keszthely-Fenékpuszta. Zalai Múzeum (Zalaegerszeg) 11, 103-111.

TÓTH, ENDRE

1987 Bemerkungen zur Kontinuität der römischen Provinzialbevölkerung in Transdanubien (Nordpannonien). In: Hänsel, B. (Hrsg.): Die Völker Südosteuropas im 6. bis 8. Jahrhundert. Südosteuropa Jahrbuch (Berlin) 17, 251-264.

1994 Das Christentum in Pannonien bis zum 7. Jahrhundert nach den archäologischen Zeugnissen. In: E. Boshof, E.-Wolff, H. (Hrsg.): Das Christentum im bairischen Raum von den Anfängen bis ins 11. Jahrhundert, Köln-Weimar-Wien, 241-272.

VIDA, TIVADAR

1996 Bemerkungen zur awarenzeitlichen Frauentracht. In: Bialeková, D.-Zábojník, J. (Hrsg.): Ethnische und kulturelle Verhältnisse an der mittleren Donau vom 6. bis zum 11. Jahrhundert. Bratislava, 107-124.

2005 Einzeln getragene germanische Scheibenfibeln im Karpatenbecken. In: Dobiat, C. (Hrsg.): Reliquiae Gentium. Festschrift für Horst Wolfgang Böhme zum 65. Geburtstag, Rahden, 429-440.

2009 Local or Foreign Romans? The Problem of the Late Antique Population of the 6th-7th Centuries AD in Pannonia. In: Quast, D. (Hrsg.): Foreingers is Early Medieval Europe. Monographien des RömischGermanisches Zentralmuseum (Mainz) 78, Mainz, 233-259.

2011 Das Gräberfeled neben dem Horreum in der Innenbefestigung von Keszthely-Fenékpuszta. In: Heinrich-Tamáska, O. (Hrsg.): Keszthely-Fenékpuszta im Kontext spätantiker Kontinuitätsforschung zwischen Noricum und Moesia. Castellum Pannonicum Pelsonense 2, Budapest-Leipzig-KeszthelyRahden, 397-455.

2012 A zárt kosaras fülbevalók eredetének kérdéséhez (Zur Herkunft der Ohrringe mit geschlossenen Körbchenanhängern). In: Vida T. (szerk.): Thesaurus Avarorum. Régészeti tanulmányok Garam Éva tiszteletére. Budapest, 63-83.

2016 Kereszténység a Kárpát-medencében a népvándorlás korában (Kr. u. 5-8. század). In: Tóth E.-Vida T.Takács I. (szerk.): Szent Márton és Pannónia. Kereszténység a római világ határán. PannonhalmaSzombathely, 93-106.

2018 A sztyeppei, a bizánci és Meroving birodalmak között, kulturális változások a Kárpát-medence nyugati felén a 6-7. században. Akadémiai doktori értekezés. Magyar Tudományos Akadémia, Budapest.

VIDA, TIVADAR-PÁSZTOR, ADRIEN

1996 Die beschlagverzierten Gürtel der Awaren am Beispiel des Inventarts von Budakalász-Dunapart, Ungarn, Grab 696. In: Daim, F. (Hrsg.): Reitervölker aus dem Osten. Hunnen und Awaren. WAMERS, EGON Ausstellungskatalog. Eisenstadt, 341-348.

2008 Salins Stil II. auf christlichen Gegenständen. Zur Ikonographie merowingerzeitlicher Kunst im 7. Jahrhundert. Zeitschrift für Archäologie des Mittelalters (Bonn) 36, 33-72. 


\section{THE KESZTHELY CULTURE TODAY}

\section{RÓBERT MÜLLER}

The concept of the Keszthely culture has changed significantly over the past 130 years. Initially, it designated the entire corpus of Late Avar finds; later, it denoted the cemeteries characterised by burials with basket earrings, stylus pins, disc brooches and snakehead bracelets that could be associated with the surviving late antique population. Later still, the Keszthely culture was believed to represent an immigrant Christian population of the Early Avar period. It was suggested that this population was made up of captives who had been transplanted to the Keszthely area. Given that parallels to the finds of the culture's early phase dated between 568 and 630-650 are known from the Balkans, Dalmatia, the eastern Alpine region and the Germanic lands, it was proposed that the label Keszthely culture should only be applied to the culture's late phase when the jewellery and costume accessories worn by women - large basket earrings, dress pins with long, split shank, pressed disc brooches and snakehead bracelets - are only attested in the Keszthely area between the mid-7th and the early 9th centuries.

Discussed here are eleven cemeteries and their grave goods from the culture's early phase. Most of these (seven of the eleven burial grounds) were uncovered in the area of the late Roman fort at Keszthely-Fenékpuszta and its immediate neighbourhood. With the exception of the cemetery by the southern fort wall, the other burial grounds were opened after 568, and in addition to the similar articles such as basket earrings, stylus pins and disc brooches, they also yielded widely differing types and differences could also be noted in burial customs, suggesting that the surviving remnants of the late antique population had been a minority. It has been suggested that the use of the horreum and Fenéki Road cemeteries had begun at some earlier date; however, the articles pre-dating 568 from the former were all extremely worn, fragmented or mended pieces, meaning that their deposition had taken place after 568 , and in fact, recent analyses have demonstrated that they can be assigned to the last third of the 6th and the initial third of the 7th century. After 568, Christian communities transplanted or arriving from different areas at different times were settled on the fringes of the Avar settlement territory with the khagan's approval. These communities enjoyed a relative measure of independence. In addition to the artefact types that were earlier regarded as distinctive to the area, the eleven cemeteries also yielded finds that have not been encountered in the other Early Avar-period cemeteries of Transdanubia (small gold tubes adorning hair-nets, stone-inlaid collar adornments, stone-inlaid quadrangular headed dress pins, disc brooches inlaid with pearl, garnet and rock crystal, onion-headed cast bronze belt sets, iron brooches with wide bow and returned foot decorated with silver plates of the Balkanic type, gold cloisonné earrings, filigree-decorated gold beads, the golden belt set and the rim mount of the silver gilt cup of Grave A from the Pusztaszentegyház-dúlő cemetery, the silver gilt bird-headed brooch [Tierwirbelfibel], plate brooches bearing a simple interlace cross motif, and a die with a depiction of "weapon dancers" [Waffentänzer] found in the fort). At the same time, certain types known from other Transdanubian cemeteries are lacking from the Keszthely area (coffin crosses, metal-inlaid folding stools [sella plicatilis], necklaces with plate pendants, amulet capsules, pendants with punched and interlace patterns, strainer spoons, cleavers [Hackmesser], mount-ornamented leg binding sets [Wadenbindengarnitur], bells, shield bosses and spears).

A survey of the complete corpus of finds strongly suggests that the population living in and around the Keszthely-Fenékpuszta fort in the Early Avar period was made up of Christian communities with a mixed background, which can be easily distinguished from the other early Avar groups in Transdanubia. The label "early Keszthely culture" seems most appropriate for the designation of this population. During the internal Avar strife around 630, the elite of the early Keszthely culture apparently sided with the group that was eventually defeated and the victorious group destroyed the fort; the community's leaders fled or were killed, and the common folk were resettled elsewhere. The fort remained unoccupied for some two centuries. There was no break in the use of three cemeteries, namely Keszthely-Dobogó, GyenesdiásDöngeleg and Kéthely-Melegoldal, between the late 6th and the 9th century, indicating the link between the early and late phase of the Keszthely culture, which is also confirmed by the transitional forms between the two found in the earliest burials of the cemeteries opened around the mid-7th century.

A cikk a Creative Commons Attribution 4.0 International License (https://creativecommons.org/licenses/by/4.0) feltételei szerint publikált Open Access közlemény, melynek szellemében a cikk bármilyen médiumban szabadon felhasználható, megosztható és újraközölhető, feltéve, hogy az eredeti szerző és a közlés helye, illetve a CC License linkje és az esetlegesen végrehajtott módosítások feltüntetésre kerülnek. (SID_1) 
